\title{
Weight of evidence approach using a TK gene mutation assay with human TK6 cells for follow-up of positive results in Ames tests: a collaborative study by MMS/JEMS
}

Manabu Yasui ${ }^{1 *}$ D, Takayuki Fukuda ${ }^{2}$, Akiko Ukai $^{1}$, Jiro Maniwa ${ }^{3}$, Tadashi Imamura ${ }^{4}$, Tsuneo Hashizume ${ }^{5}$, Haruna Yamamoto ${ }^{5}$, Kaori Shibuya ${ }^{5}$, Kazunori Narumi ${ }^{6}$, Yohei Fujiishi ${ }^{6}, E^{2}$ iko Okada ${ }^{6}$, Saori Fujishima', Mika Yamamoto ${ }^{8}$, Naoko Otani ${ }^{8}$, Maki Nakamura ${ }^{2}$, Ryoichi Nishimura ${ }^{2}$, Maya Ueda ${ }^{9}$, Masayuki Mishima ${ }^{10}$, Kaori Matsuzaki ${ }^{10}$, Akira Takeiri $^{10}$, Kenji Tanaka ${ }^{10}$, Yuki Okada ${ }^{11}$, Munehiro Nakagawa ${ }^{12}$, Shuichi Hamada ${ }^{2}$, Akihiko Kajikawa ${ }^{12}$, Hiroshi Honda ${ }^{13}$, Jun Adachi ${ }^{14}$, Kentaro Misaki ${ }^{15}$, Kumiko Ogawa $^{16}$ and Masamitsu Honma ${ }^{1}$

\begin{abstract}
Background: Conflicting results between bacterial mutagenicity tests (the Ames test) and mammalian carcinogenicity tests might be due to species differences in metabolism, genome structure, and DNA repair systems. Mutagenicity assays using human cells are thought to be an advantage as follow-up studies for positive results in Ames tests. In this collaborative study, a thymidine kinase gene mutation study (TK6 assay) using human lymphoblastoid TK6 cells, established in OECD TG490, was used to examine 10 chemicals that have conflicting results in mutagenicity studies (a positive Ames test and a negative result in rodent carcinogenicity studies).
\end{abstract}

Results: Two of 10 test substances were negative in the overall judgment (20\% effective as a follow-up test). Three of these eight positive substances were negative after the short-term treatment and positive after the $24 \mathrm{~h}$ treatment, despite identical treatment conditions without S9. A toxicoproteomic analysis of TK6 cells treated with 4-nitroanthranilic acid was thus used to aid the interpretation of the test results. This analysis using differentially expressed proteins after the $24 \mathrm{~h}$ treatment indicated that in vitro specific oxidative stress is involved in false positive response in the TK6 assay.

Conclusions: The usefulness of the TK6 assay, by current methods that have not been combined with new technologies such as proteomics, was found to be limited as a follow-up test, although it still may help to reduce some false positive results (20\%) in Ames tests. Thus, the combination analysis with toxicoproteomics may be useful for interpreting false positive results raised by $24 \mathrm{~h}$ specific reactions in the assay, resulting in the more reduction ( $>20 \%$ ) of false positives in Ames test.

Keywords: TK6 assay, Human lymphoblastoid TK6 cells, Ames test, Follow-up, Weight of evidence approach, Toxicoproteomics

\footnotetext{
* Correspondence: m-yasui@nihs.go.jp

'Division of Genetics and Mutagenesis, National Institute of Health Sciences,

3-25-26 Tono-machi, Kawasaki-ku, Kawasaki, Kanagawa 210-9501, Japan

Full list of author information is available at the end of the article
} 


\section{Introduction}

DNA reactive substances may directly damage DNA even when present at low levels leading to mutations and, therefore, potentially initiating cancer. A positive result in the Ames test has a significant influence on the development of new drugs and chemical substances, and in many cases, mutagenic chemicals are dropped from drug/chemical development at an early stage. In the guidelines from the ICH M7 (ICH: International Council for Harmonization of Technical Requirements for Pharmaceuticals for Human Use), Ames-positive substances are considered as DNA reactive substances [1] and require a great deal of labor for subsequent development and manufacturing. Continued development of components with Ames-positive results requires in vivo tests, such as transgenic rodent mutation assays as follow-up testings. However, problems such as costs and labor burden of in vivo testing can be prohibitive.

Furthermore, such testing does not fit the $3 \mathrm{R}$ principles for animal welfare $[2,3]$. Positive results in the Ames test correlate well with carcinogenicity in rodents, with the concordance (Ames-negative and carcinogenicnegative) of approximately $80 \%[4,5]$. This indicates that there are approximately $20 \%$ of chemical substances that are positive in Ames tests and negative for carcinogenicity test. In fact, it is considered that some of these substances are unrelated to human carcinogenesis. For example, fexinidazole, a drug for sleeping sickness, is positive for the Ames test but negative for all in vitro (micronucleus test in human lymphocytes) and in vivo genotoxicity tests (ex vivo unscheduled DNA synthesis in rats; bone marrow micronucleus test in mice). Tweats et al. [6] demonstrated that fexinidazole is metabolically activated by a bacterial-specific nitroreductase reaction and is thus positive in the Ames test alone. Thus, if it is possible to prove that the Ames test positive is a bacteria-specific reaction and has a low risk of carcinogenicity in humans, useless a follow-up testing in whole animals can be avoided.

The consideration of the mode of action is the critical establishment of non-animal testing for the safety evaluation of chemicals. The Organization for Economic Cooperation and Development (OECD) have been vigorously developing "adverse outcome pathway (AOP)" and "integrated approaches to testing and assessment (IATA)" combining in silico and in vitro information based on AOP [7]. The AOP and IATA would contribute to a precise toxicological evaluation based on the weight of evidence (WoE) including genotoxicity $[7,8]$ and the derivation of regulatory conclusions. Since the in vivo testing is prohibited for the safety evaluation of cosmetic ingredients, the use of a WoE approach based on in vitro testing is relatively advanced in the cosmetic industry [9]. An example is the toxicity evaluation of
Basic Brown 17, used as a hair coloring agent for cosmetics. Basic Brown 17 is positive in Ames test, but negative in mutation assays using mouse lymphoma (two loci of TK and HPRT) and in in vitro micronucleus test using mammalian cells. Furthermore, Basic Brown 17 is negative in the comet assay with 3-D reconstituted human skin cells $[10,11]$. Thus, based on WoE [12], Basic Brown 17 can be considered to show negligible potential for in vivo genotoxicity, and no additional testing is reported [10]. Furthermore, omics technologies, such as transcriptome and proteome, play a crucial role in implementing a WoE approach. Ates et al. [13] used an in vitro transcriptomics approach to evaluate the genotoxicity predictions for cosmetic ingredients that were negative by in silico analysis but positive by the Ames test. Transcriptomics data were reported to provide needed mechanistic information for toxicity assessments at the gene expression and metabolic pathway levels. In addition, Kirkland et al. [14, 15] also reported that follow-up in vitro tests, such as for gene expression profiling, may aid significantly in interpretation of the relevance for humans of the in vitro genotoxicity results visà-vis in vivo genotoxicity or carcinogenicity. Thus, the WoE approaches are also useful for a follow-up strategy for positive Ames tests, shifting steadily toward new evaluation strategies for human risk while reducing dependence on animal experiments.

Based on the current literature, we focused on the utility of the thymidine kinase gene (TK) mutation assay using human TK6 cells for the follow-up of positive Ames tests. Conflicting results between Ames tests and mammalian carcinogenicity tests might be caused by species differences in metabolism, genome structure, and DNA repair systems. TK6 cells express human metabolic enzymes and have a chromatin structure. Furthermore, the cells are positive for p53 protein-related functions (competent DNA repair systems) [16]. TK6 cells might be useful for in a WoE approach to scrutinize positive results in the Ames test. However, little is known about the utility of the assay for this purpose. Thus, the present study used the TK6 assay for the follow-up of Ames test results with 10 non-carcinogenic chemicals that were Ames-positive in a collaborative study with 10 laboratories in Japan. Assays were conducted for a short-term ( $4 \mathrm{~h}$ in the presence and absence of rat liver S9) and long-term (24 h in the absence of S9) treatments. Furthermore, we explored the integration of toxicoproteomics analysis with TK6 assays to help interpret test results and increase the utility of $\mathrm{WoE}$.

\section{Materials and methods}

\section{Participants and test substances}

Ten laboratories in Japan, including pharmaceutical and chemical companies, contract laboratories, and public 
institutes, conducted TK6 assays for 10 test substances in the collaborative study (Table 1). We purchased the test substances from FUJIFILM Wako Pure Chemical Corp. (Osaka, Japan), Tokyo Chemical Industry Co., LTD. (Tokyo, Japan), or Sigma-Aldrich (St. Louis, USA). Most of the test substances were dissolved in dimethyl sulfoxide (DMSO) as a solvent, except that ethanol was used for 1-nitronaphthalene (Table 1).

\section{Cell culture}

The human lymphoblast cell line TK6 was purchased from the Japanese Collection of Research Bioresources cell bank and the American Type Culture Collection. Cells were cultured at $37^{\circ} \mathrm{C}$ with $5 \% \mathrm{CO}_{2}$ in an RPMI medium containing 10\% horse serum (JRH Bioscience), $200 \mu \mathrm{g} / \mathrm{mL}$ sodium pyruvate (Wako Pure Chemical Industries, Ltd. and Thermo Fisher (Gibco)), $100 \mathrm{U} / \mathrm{mL}$ penicillin, and $100 \mu \mathrm{g} / \mathrm{mL}$ streptomycin (Nacalai Tesque Inc. and Thermo Fisher (Gibco)). Reagent manufacturers are not necessarily unified, and some research institutions have procured equivalent reagents from other manufacturers.

\section{The treatment of test substances and dose finding}

In principle, this collaborative study conducted the treatment of test substances, the dose finding, and the main test of TK6 assays, according to the OECD Guideline TG490 [17]. We optimized the protocol for TK6 assay prior to this collaborative study. The laboratory of the National Institute of Health Sciences carefully supported the experimental procedures such as chemical treatments and colony counting for TK6 assay performed by each laboratory. Briefly, test substances were dissolved in an appropriate solvent (DMSO or ethanol) and then serially diluted to prepare final concentrations. Details of 10 test substances are shown in Table 2. In the absence $(150 \mathrm{mM} \mathrm{KCl})$ or presence of rat liver S9 mix (final concentration $4.5 \%)$, cells $\left(2 \times 10^{7}\right.$ cells) were exposed to a test substance and cultured for $4 \mathrm{~h}$. Rat liver S9 was purchased from Oriental Yeast Co., Ltd. and IEDA TRAD ING Corp. In cases where the short-term treatment (4 h) showed negative results, the $24 \mathrm{~h}$ treatment without S9 mix was conducted. Cyclophosphamide (CP, Fujifilm Wako Pure Chemical Industries, Ltd.) was used as a positive control $(2.5-3 \mu \mathrm{g} / \mathrm{mL})$ for metabolic activation, and methyl methanesulfonate (MMS, Tokyo Chemical Industry Co., Ltd., and Sigma Aldrich) was used as a positive control $(3-5 \mu \mathrm{g} / \mathrm{mL}$ for $4 \mathrm{~h}$ and $1-2.5 \mu \mathrm{g} / \mathrm{mL}$ for $24 \mathrm{~h}$ treatments) for non-metabolic activation. The $4 \mathrm{~h}$ and $24 \mathrm{~h}$ treatments were conducted by shaking and static exposures, respectively. After treatment with test substances, cells were centrifuged ( $1000 \mathrm{rpm}, 5 \mathrm{~min})$, supernatants were removed, and cells were washed with a serum-free medium or Hank's Balanced Salt Solution. After centrifugation $(1000 \mathrm{rpm}, 5 \mathrm{~min})$ to remove the supernatant, cells $\left(2 \times 10^{7}\right.$ cells $)$ were dispersed in an RPMI medium containing $10 \%$ serum, and cell concentration was measured. Treated cells were cultured at $37^{\circ} \mathrm{C}$ with $5 \% \mathrm{CO}_{2}$ condition and used for TK6 assays. At that time, to calculate the cloning efficiency (CE) (Eq.

Table 1 Participantes and test substances in the collaborative study

\begin{tabular}{|c|c|c|c|c|c|c|}
\hline No. & $\begin{array}{l}\text { Participating } \\
\text { Laboratories }\end{array}$ & Investigators & Test Substances & $\begin{array}{l}\text { CAS } \\
\text { No. }\end{array}$ & Manufacturer, Lot\# & Solvent \\
\hline 1 & Ina Research Inc. & Tadashi Imamura & $\begin{array}{l}\text { 4- } \\
\text { (Chloroacetyl)acetanilide }\end{array}$ & $\begin{array}{l}140- \\
49-8\end{array}$ & $\begin{array}{l}\text { FUJIFILM Wako Pure Chemical } \\
\text { Corporation, Lot\#KPJ1678 }\end{array}$ & DMSO \\
\hline 2 & Japan Tobacco Inc. & $\begin{array}{l}\text { Tsuneo Hashizume, Haruna } \\
\text { Yamamoto, Kaori Shibuya }\end{array}$ & $\begin{array}{l}\text { 2-(Chloromethyl) } \\
\text { pyridine } \mathrm{HCl}\end{array}$ & $\begin{array}{l}6959- \\
47-3\end{array}$ & $\begin{array}{l}\text { Tokyo Chemical Industry Co., } \\
\text { Ltd., Lot\#7BOQI-IC }\end{array}$ & DMSO \\
\hline 3 & Yakult Central Institute & $\begin{array}{l}\text { Kazunori Narumi, Yohei Fujiishi, } \\
\text { Emiko Okada }\end{array}$ & 2,6-Diaminotoluene & $\begin{array}{l}823- \\
40-5\end{array}$ & $\begin{array}{l}\text { Tokyo Chemical Industry Co., } \\
\text { Ltd., Lot\#IUL6B }\end{array}$ & DMSO \\
\hline 4 & $\begin{array}{l}\text { Chemicals Evaluation and } \\
\text { Research Institute, Japan }\end{array}$ & Saori Fujishima & 2,5-Diaminotoluene & $\begin{array}{l}95-70- \\
5\end{array}$ & $\begin{array}{l}\text { Tokyo Chemical Industry Co., } \\
\text { Ltd., Lot\#QFIJE }\end{array}$ & DMSO \\
\hline 5 & Astellas Pharma Inc. & Mika Yamamoto, Naoko Otani & HC Blue No.2 & $\begin{array}{l}33229- \\
34-4\end{array}$ & $\begin{array}{l}\text { SIGMA-ALDRICH, } \\
\text { Lot\#STBF9635V }\end{array}$ & DMSO \\
\hline 6 & BoZo Research Center Inc. & $\begin{array}{l}\text { Takayuki Fukuda, Maki Nakamura, } \\
\text { Ryoichi Nishimura, Shuichi Hamada }\end{array}$ & 8-Hydroxyquinoline & $\begin{array}{l}148- \\
24-3\end{array}$ & $\begin{array}{l}\text { Tokyo Chemical Industry Co., } \\
\text { Ltd., Lot\#5PDSI-RB }\end{array}$ & DMSO \\
\hline 7 & $\begin{array}{l}\text { BioSafety Research Center } \\
\text { Inc. }\end{array}$ & Maya Ueda & lodoform & $\begin{array}{l}75-47- \\
8\end{array}$ & $\begin{array}{l}\text { FUJIFILM Wako Pure Chemical } \\
\text { Corporation, Lot\#PDH1055 }\end{array}$ & DMSO \\
\hline 8 & $\begin{array}{l}\text { Chugai Pharmaceutical Co., } \\
\text { Ltd }\end{array}$ & $\begin{array}{l}\text { Masayuki Mishima, Kaori Matsuzaki, } \\
\text { Akira Takeiri, Kenji Tanaka }\end{array}$ & 4-Nitroanthranilic acid & $\begin{array}{l}619- \\
17-0\end{array}$ & $\begin{array}{l}\text { Tokyo Chemical Industry Co., } \\
\text { Ltd., Lot\#AGM01-AGMQ }\end{array}$ & DMSO \\
\hline 9 & TEIJIN PHARMA LIMITED & Yuki Okada, Takafumi Kimoto & 1-Nitronaphthalene & $\begin{array}{l}86-57- \\
7\end{array}$ & $\begin{array}{l}\text { Tokyo Chemical Industry Co., } \\
\text { Ltd., Lot\#BGF8A-MD }\end{array}$ & Ethanol \\
\hline 10 & LSI Medience Corporation & $\begin{array}{l}\text { Munehiro Nakagawa, Akihiko } \\
\text { Kajiwara }\end{array}$ & $\begin{array}{l}\text { 4-Nitro-O- } \\
\text { phenylenediamine }\end{array}$ & $\begin{array}{l}99-56- \\
9\end{array}$ & $\begin{array}{l}\text { Tokyo Chemical Industry Co., } \\
\text { Ltd., Lot\#NMEDH }\end{array}$ & DMSO \\
\hline
\end{tabular}


Table 2 Testing chemicals for the positive results in bacterial reverse mutation assay and the negative results in carcinogenicity studies $^{a}$

\begin{tabular}{|c|c|c|c|c|c|c|c|}
\hline \multirow[t]{2}{*}{ No. } & \multirow[t]{2}{*}{ Chemical Name } & \multicolumn{4}{|c|}{ The Positive Results in Bacterial Reverse Mutation Assay } & \multicolumn{2}{|c|}{$\begin{array}{l}\text { Carcinogenicity } \\
\text { Studies }\end{array}$} \\
\hline & & $\begin{array}{l}\text { Without } \\
\text { S9 }\end{array}$ & $\begin{array}{l}\text { With } \\
\text { S9 }\end{array}$ & The Highest Specific Activity ${ }^{b}$ and the Strain & Ref. & & Ref. \\
\hline 1 & $\begin{array}{l}\text { 4-(Chloroacetyl)- } \\
\text { acetanilide }\end{array}$ & Neg & Pos & 600 revertants/mg in TA1538 with S9 & $\begin{array}{l}{[18,} \\
19]\end{array}$ & Neg & [20] \\
\hline 2 & $\begin{array}{l}\text { 2-(Chloromethyl) } \\
\text { pyridine } \mathrm{HCl}\end{array}$ & Pos & Pos & 98.6 revertants/mg in TA100 with 59 & {$[21]$} & Neg & [22] \\
\hline 3 & 2,6-Diaminotoluene & Neg & Pos & 1703 revertants/mg in TA100 with S9 & {$[23]$} & Neg & [24] \\
\hline 4 & 2,5-Diaminotoluene & Neg & Pos & 8060 revertants/mg in TA98 and 3840 revertants/mg in TA100 with S9 & {$[25]$} & Neg & [26] \\
\hline 5 & HC Blue No.2 & Pos & Pos & 153.6 revertants/mg in TA98 with 59 & $\begin{array}{l}{[27,} \\
28]\end{array}$ & Neg & [29] \\
\hline 6 & 8-Hydroxyquinoline & Neg & Pos & $\begin{array}{l}\text { 21,400 revertants/mg in TA97 and 16,000 revertants/mg in TA100 with } \\
\text { S9 }\end{array}$ & [28] & Neg & [30] \\
\hline 7 & lodoform & Pos & Pos & 465 revertants/mg in TA98 and 450 revertants/mg in TA100 with S9 & {$[31]$} & Neg & [32] \\
\hline 8 & 4-Nitroanthranilic acid & Pos & Pos & $\begin{array}{l}3600 \text { revertants/mg in TA1535 and } 2830 \text { revertants/mg in TA100 with } \\
\text { S9 }\end{array}$ & {$[33]$} & Neg & [34] \\
\hline 9 & 1-Nitronaphthalene & Pos & Pos & $\begin{array}{l}14,700 \text { revertants/mg in TA100 without } S 9 \text { and } 12,500 \text { revertants/mg } \\
\text { in TA100 with } S 9\end{array}$ & {$[35]$} & Neg & {$[36]$} \\
\hline 10 & $\begin{array}{l}\text { 4-Nitro-o- } \\
\text { phenylenediamine }\end{array}$ & Pos & Pos & 41,400 revertants/mg in TA100 without S9 & $\begin{array}{l}{[37-} \\
40]\end{array}$ & Neg & [41] \\
\hline
\end{tabular}

${ }^{a}$ Pos Positive, Neg Negative

${ }^{\mathrm{b}}$ Specific activity value indicating that strong mutagenicity is observed in the Ames test is approximately 1000 (revertants / mg) or more, and to be calculated as below

Specific activity (revertants $/ \mathrm{mg})=\{($ Number of colonies per plate at the dose value) - (Number of colonies per plate in negative control test) $\} / T h e$ dose value ( $\mu \mathrm{g}$ ) X 1000

1), the cells were cultured in a 96-well microplate at a concentration of about 1.6 cells/well for 2 weeks.

$\mathrm{CE}$, the cell colony formation rate, was calculated using Eq. 1 according to the Poisson distribution equation. EW was the number of wells without colonies, and TW was the total number of wells. $\mathrm{N}$ was the average number of cells per well $(N=1.6)$.

$$
\mathrm{CE}=-\ln (\mathrm{EW} / \mathrm{TW}) / \mathrm{N}
$$

Additionally, CE was adjusted by the following calculation (Eq. 2) due to cell loss when exposure caused cytotoxicity. "The number of cells at the end of the treatment" was the number of cells obtained after centrifugation at the end of the treatment in the abovedescribed exposure treatment of the test substance. The "cell number at the start of treatment" was $2 \times 10^{7}$.

Adjusted $\mathrm{CE}=\mathrm{CE} \times$ number of cells at end of treatment/number of cells at the start of treatment

CE0 seeding, in which cells were seeded immediately after treatment, and CE3 seeding, in which cells were seeded 3 days after treatment, to examine cell viability in the TK6 assay described below. The relative cell viability RS0 (\%) just after the treatment with the test substance was calculated from CE0, following Eq. 3. The survival rate of the negative control group was defined as $100 \%$.

$$
\begin{array}{r}
\text { RSO }(\%)=\text { adjusted CE0 of treatment culture/ } \\
\text { adjusted CE0 of solvent control } \times 100
\end{array}
$$

\section{The main test of the TK6 assay}

The TK 6 assay is conducted between 20 and 10\% RS0 as a maximum dose if cytotoxicity is observed. If no precipitate or limiting cytotoxicity was observed, the maximum dose was the lowest concentration among $10 \mathrm{mM}$, $2 \mathrm{mg} / \mathrm{mL}$, or $2 \mu \mathrm{L} / \mathrm{mL}$ of the test substance. When the main TK6 assay was difficult to conduct under the condition of RS0 values from 20 to $10 \%$, the test was conducted between 20 and $10 \%$ relative total growth (RTG), described later, as a maximum dose.

Besides RS0, relative suspension growth (RSG) and RTG as other cytotoxicity indices (Eq. 4) were used. When cells were cultured for 3 days after treatment with the test substance, suspension cell growth ratio 1 (SG1) was the growth ratio from day 0 to day 1 (cell concentration on day $1 /$ cell concentration on day 0 ). The suspension cell growth ratio 2 (SG2) was the growth ratio from day 1 to day 2 (cell concentration on day 2/cell concentration on day 1 ). The RSG value was calculated 
by dividing the total SG value of the untreated group for 3 days by the total SG value of the treated group for the same 3 days (Eq. 4).

On the third day of culture, CE3 plates for determining plating efficiency and mutant frequency (MF) plates for mutation detection were prepared. CE3 plates were seeded in 96-well microplates at a concentration of about 1.6 cells/well. The MF plates were seeded in 96well microplates at 40,000 cells/well in the presence of $3 \mu \mathrm{g} / \mathrm{mL}$ of trifluorothymidine (Sigma Aldrich).

$$
\begin{aligned}
& \mathrm{RSG}=[\mathrm{SG} 1(\text { treated }) \times \mathrm{SG} 2(\text { treated })(4) \\
& \times \mathrm{SG} 3(\text { treated })] /[\mathrm{SG} 1(\text { control }) \\
& \times \mathrm{SG} 2(\text { control }) \times \mathrm{SG} 3(\text { control })] \\
& \mathrm{RTG}(\%)=\mathrm{RSG} \times \mathrm{RS} 3 \\
& \mathrm{RS} 3(\%)=\text { treated CE3 } / \text { control CE } 3 \times 100
\end{aligned}
$$

Mutant colonies in MF plates were calculated using Eq. 7 using the Poisson distribution. EW was the number of wells without colonies, and TW was the total number of wells. $\mathrm{N}$ was the average number of cells per well ( $N=40,000$ in this study). The data were statistically analyzed by Omori's method, a modified Dunnett's procedure for identifying clear negatives, a Simpson-Margolin procedure for detecting downturn data, and a trend test to evaluate the dose dependency [42, 43]. The acceptability criterion for the test was that the MF value of the positive control group of each laboratory was increased with statistical significance compared with that of the concurrent negative control group.

$$
\mathrm{MF}=[-\ln (\mathrm{EW} / \mathrm{TW}) / \mathrm{N}] / \text { treated CE3 }
$$

\section{Sample preparation for proteomic analysis}

We conducted a proteomic analysis using TK6 cells treated by 4-nitroanthranilic acid that was negative in the short-term treatment and positive in the $24 \mathrm{~h}$ treatment. HC Blue No. 2 gave also same test results. 4Nitroanthranilic acid, but not HC Blue No. 2, increased clearly the mutant efficiency in dose-dependent manner even at the low-dose range in the $24 \mathrm{~h}$ treatment (Additional file 1 (Table S1 (No.8)), we selected the chemical for the proteomics. Cell treatment with 4-nitroanthranilic acid was the same as the short-time treatment $(4 \mathrm{~h}$, -S9mix) and long-term treatment (24h, - S9mix) in the TK6 assay. Treatment concentrations were 0,400 , and $800 \mu \mathrm{g} / \mathrm{mL}$, relatively low toxicity doses, to clearly measure biological responses to the chemical. After treatment, the supernatant was removed by centrifugation $(1000 \mathrm{rpm}, 5$ min). The cell pellet $\left(6 \times 10^{6}\right.$ cells) was washed with a 10 $\mathrm{mL}$ of ice-cold phosphate-buffered saline (PBS) and centrifuged (repeated twice on ice throughout). The cells were resuspended in $3 \mathrm{~mL}$ of $\mathrm{PBS}$ containing the protease inhibitor cocktail (Roche), complete EDTA-free (Roche), and $2 \times 10^{6}$ cells each were dispensed into three precooled $2.0 \mathrm{~mL}$ tubes. After centrifugation, supernatants were removed again, and tubes containing cell pellets were immersed in liquid nitrogen to freeze the cell pellet and stored at $-80^{\circ} \mathrm{C}$.

Each frozen cell pellet was mixed with PTS (phase transfer surfactant) buffer and boiled at $95^{\circ} \mathrm{C}$ for $5 \mathrm{~min}$ [44]. Lysates were further sonicated three times ( $15 \mathrm{~min}$ per cycle) with a Bioruptor sonicator (Cosmo Bio, Tokyo, Japan). Samples were then reduced with $10 \mathrm{mM}$ TCEP (tris(2-carboxyethyl) phosphine), alkylated with $20 \mathrm{mM}$ iodoacetamide, and sequentially, digested with trypsin (protein weight: $1 / 50$ ) and Lys-C (protein weight: $1 / 50$ ) for $16 \mathrm{~h}$ at $37^{\circ} \mathrm{C}$. Peptides were elucidated by centrifugation for $10 \mathrm{~min}$ at $20,000 \mathrm{~g}$ and desalted on a C18SCX StageTips [45].

\section{LC-MS/MS analysis}

LC-MS/MS was conducted by coupling an UltiMate 3000 Nano LC system (Thermo Scientific, Bremen, Germany) and an HTC-PAL autosampler (CTC Analytics, Zwingen, Switzerland) to a Q Exactive hybrid quadrupole-Orbitrap mass spectrometer (Thermo Scientific). Peptides were loaded on an analytical column $(75 \mu \mathrm{m} \times 30 \mathrm{~cm}$, packed in-house with ReproSil-Pur C18AQ, $1.9 \mu \mathrm{m}$ resin, Dr. Maisch, Ammerbuch, Germany) and separated at a flow rate of $280 \mathrm{~nL} / \mathrm{min}$ using a 45 min gradient from 5 to $35 \%$ of solvent $\mathrm{B}$ (solvent $\mathrm{A}$, $0.1 \%$ FA and $2 \%$ acetonitrile; solvent $\mathrm{B}, 0.1 \% \mathrm{FA}$ and 90\% acetonitrile). The Q Exactive instrument was operated in the data-dependent mode. Survey full-scan MS spectra $(\mathrm{m} / \mathrm{z} 350-1800)$ were acquired in the Orbitrap with 70,000 resolution after the accumulation of ions to a $3 \times 10^{6}$ target value. Dynamic exclusion was set to $10 \mathrm{~s}$. The 12 most intense multiplied charged ions $(\mathrm{z} \geq 2)$ were sequentially accumulated to a $1 \times 10^{5}$ target value and fragmented in the collision cell by higher-energy collisional dissociation (HCD) with a maximum injection time of $120 \mathrm{~ms}$ and 35,000 resolution. Typical mass spectrometric conditions were: spray voltage, $2 \mathrm{kV}$; heated capillary temperature, $250^{\circ} \mathrm{C}$; and normalized HCD collision energy, 25\%. The MS/MS ion selection threshold was set to $2.5 \times 10^{4}$ counts. A $2.0 \mathrm{Da}$ isolation width was chosen.

Raw MS data were processed by MaxQuant (version 1.6.3.3) supported by the Andromeda search engine for peak detection and quantification. MS/MS spectra were searched against the UniProt human database with the following search parameters: full tryptic specificity, up to two missed cleavage sites, carbamidomethylation of cysteine residues set as a fixed modification, and $\mathrm{N}$-terminal protein acetylation and methionine oxidation as variable modifications. Search results were filtered to a maximum 
FDR (false discovery rate) of 0.01 at protein, and PSM levels.

\section{Extraction of differentially expressed proteins}

All NaN values of $\log _{2}$ LFQ intensities were converted to -7 , which is approximately equivalent to the minimum value of the LFQ intensities observed in the present study. Then, fold change values were calculated by dividing LFQ intensities (antilogarithms of the $\log _{2}$ LFQ intensities) into sample treated groups by intensities in non-treated (control) groups, respectively ( 4 and $24 \mathrm{~h}$ treated groups). Then, $\log _{2}$ fold changes were calculated. Finally, differentially expressed proteins (DEPs) that were notably expressed in each sample treated group were identified based on $\log _{2}$ fold change of $\geq 2$. Next, to analyze specific effects in repeated treatments at the highest dose, DEPs in $24 \mathrm{~h} 800 \mu \mathrm{g} / \mathrm{mL}$ group was subjected to further screening based on $\log _{2}$ fold change between 24-h $800 \mu \mathrm{g} / \mathrm{mL}$ group and other groups $\geq 1$. Thereby, the specific DEPs in $24 \mathrm{~h}$ $800 \mu \mathrm{g} / \mathrm{mL}$ group were thus identified. $\log _{2}$ fold changes in LFQ intensities were used to generate a heatmap using the $R$ package (heatmap3).

\section{Enrichment analysis}

Enrichment analysis was used to interpret the biological processes and molecular functions of DEPs. DAVID bioinformatics v6.8 (https://david.ncifcrf.gov/) was used for enrichment analyses to annotate DEPs to their correlated GO (Gene Ontology) terms and pathways. Specifically, Gene Ontology (GOTERM_BP_DIRECT, GOTERM_CC_ DIRECT, GOTERM_MF_DIRECT), and Protein_Domains (INTERPRO, PIR_SUPERFMILY, SMART) were analyzed. Moreover, since DNA damage and oxidative stress were considered as important mechanisms to interpret genotoxicity test results, enrichment scores (the Expression Analysis Systematic Explorer (EASE) $p$-value) of some related terms, such as GO:0006974 (cellular response to DNA damage stimulus) and GO:0006979 (response to oxidative stress) were respectively evaluated even if they were not statistically significant. Statistical significance was expressed as -log (the EASE $p$-value) and was illustrated as bar charts for comparison.

\section{Results}

\section{Negative and positive control data}

The TK6 assay conducted by each laboratory were presented in Fig. 1 (No.1-10) and Table 3. The mutant frequencies of negative control were 2.5 to $16.9 \times 10^{-6}$ (mean $6.36 \times 10^{-6}$ ) for the short treatment without S9 mix, 1.7 to $16.8 \times 10^{-6}$ (mean $6.78 \times 10^{-6}$ ) for the short treatment with S9 mix, and 2.3 to $15.5 \times 10^{-6}$ (mean $9.09 \times 10^{-6}$ ) for the $24 \mathrm{~h}$ treatment without S9 mix. According to the laboratory of the National Institute of Health Sciences, the historical spontaneous mutant frequency is 4 to $10 \times 10^{-6}$, these mean values almost accepted the criteria by OECD TG490 [17]. In addition, the mutant frequencies of the concurrent positive controls were 9.4 to $71.7 \times 10^{-6}$ (mean $30.1 \times 10^{-6}$ ) for MMS during the short treatment without S9 mix, 10.4 to $57.8 \times 10^{-6}$ (mean $28.6 \times 10^{-6}$ ) for $\mathrm{CP}$ during the short treatment with $\mathrm{S} 9 \mathrm{mix}$, and 18.2 to $120 \times 10^{-6}$ (mean $61.6 \times 10^{-6}$ ) for MMS during the $24 \mathrm{~h}$ treatment without S9 mix. Thus, the concurrent positive controls produced a statistically significant increase compared with the concurrent negative control. For more details, see Additional file 1 (Table S1 (No.1-10)) attached in this paper. The summary of statistics analysis by Omori's method in each test substance was provided in Additional file 2 (Table S2).

\section{4-(Chloroacetyl) acetanilide}

4-(Chloroacetyl) acetanilide was prepared by dissolving in DMSO. Dose levels of 4-(chloroacetyl) acetanilide were set at $0.5,1,1.5$ and $2 \mu \mathrm{g} / \mathrm{mL}$ in the short-term treatment $(-\mathrm{S} 9), 5,10,14,16$, and $17 \mu \mathrm{g} / \mathrm{mL}$ with the short-term treatment $(+\mathrm{S} 9)$, and $0.5,1.0,1.2$, and $1.4 \mu \mathrm{g} /$ $\mathrm{mL}$ with the long-term treatment based on the results of the dose range-finding tests. A positive response was statistically significant in the Dunnett type test in the short-term (-S9) and long-term treatments. However, no statistically significant linear trends were observed (Additional file 2 (Table S2)). Both MF values clearly exceeded those of the solvent control group. Therefore, based on expert judgment, 4-(chloroacetyl) acetanilide was judged to be positive.

\section{2-(Chloromethyl) pyridine $\mathrm{HCl}$}

About $80 \%$ cytotoxicity (relative colony efficiency) was observed at $60 \mu \mathrm{g} / \mathrm{mL}$ in the absence or at $100 \mu \mathrm{g} / \mathrm{mL}$ in the presence of S9. Regardless of metabolic activation, a clear concentration-dependent increase of MF was observed under the condition used in this study. Longterm treatment was not applied. The test chemical, 2(chloromethyl) pyridine $\mathrm{HCl}$, was judged as positive.

\section{2,6-Diaminotoluene}

More than $80 \%$ cytotoxicity was observed at $2000 \mu \mathrm{g} / \mathrm{mL}$ in the long-term treatment. Statistically significant increases of MF were observed after the short-term treatment with metabolic activation and after the long-term treatment. Thus, 2,6-diaminotoluene was judged to be positive.

\section{2,5-Diaminotoluene}

About $80 \%$ of cytotoxicity was observed at $20.0 \mu \mathrm{g} / \mathrm{mL}$ in the absence or at $200 \mu \mathrm{g} / \mathrm{mL}$ in the presence of S9 for the short-term treatment and $10.0 \mu \mathrm{g} / \mathrm{mL}$ for the longterm treatment. Statistically significant increases of 

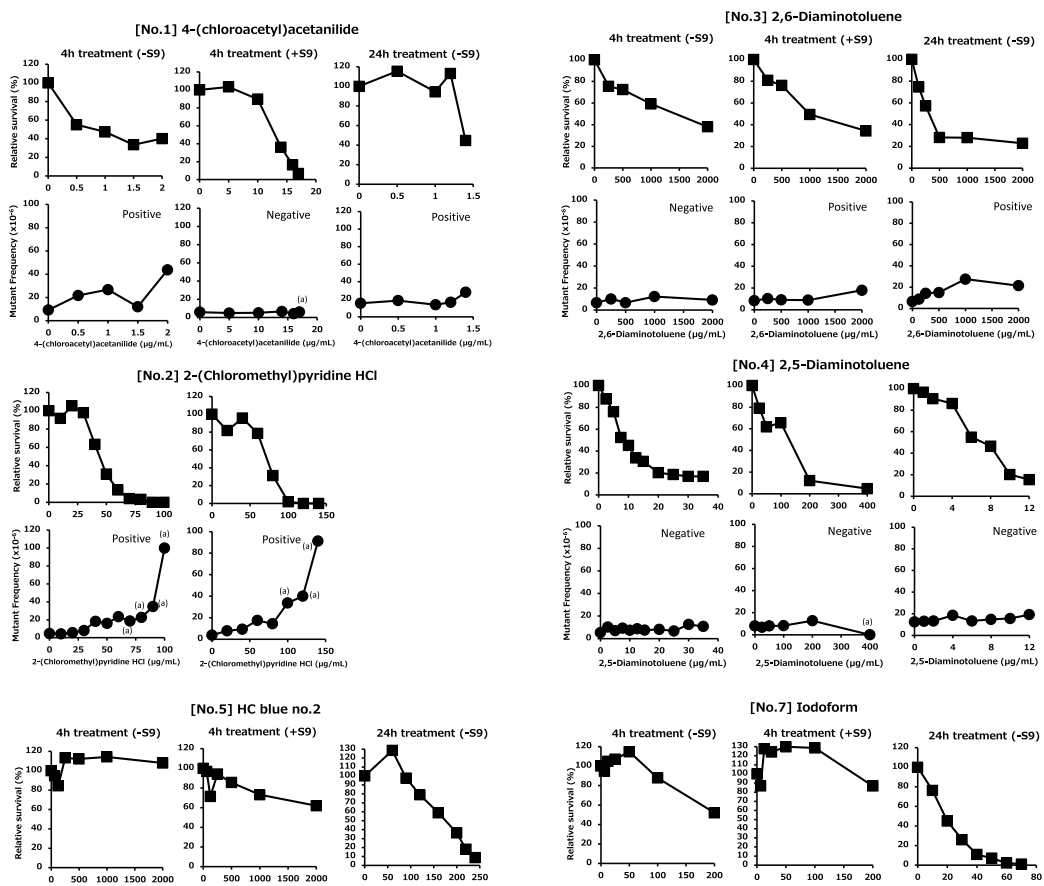

[No.5] HC blue no.2
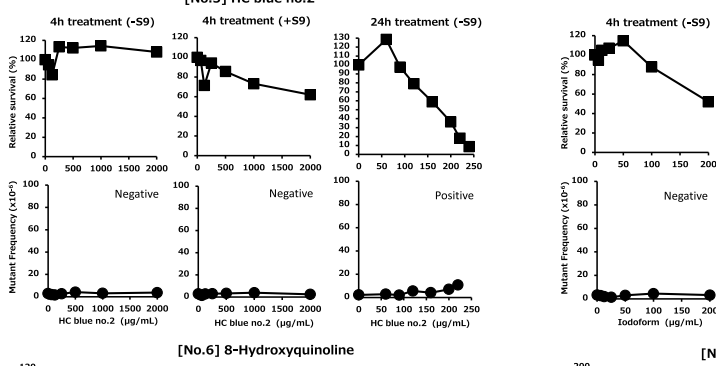

[No.7] Iodoform
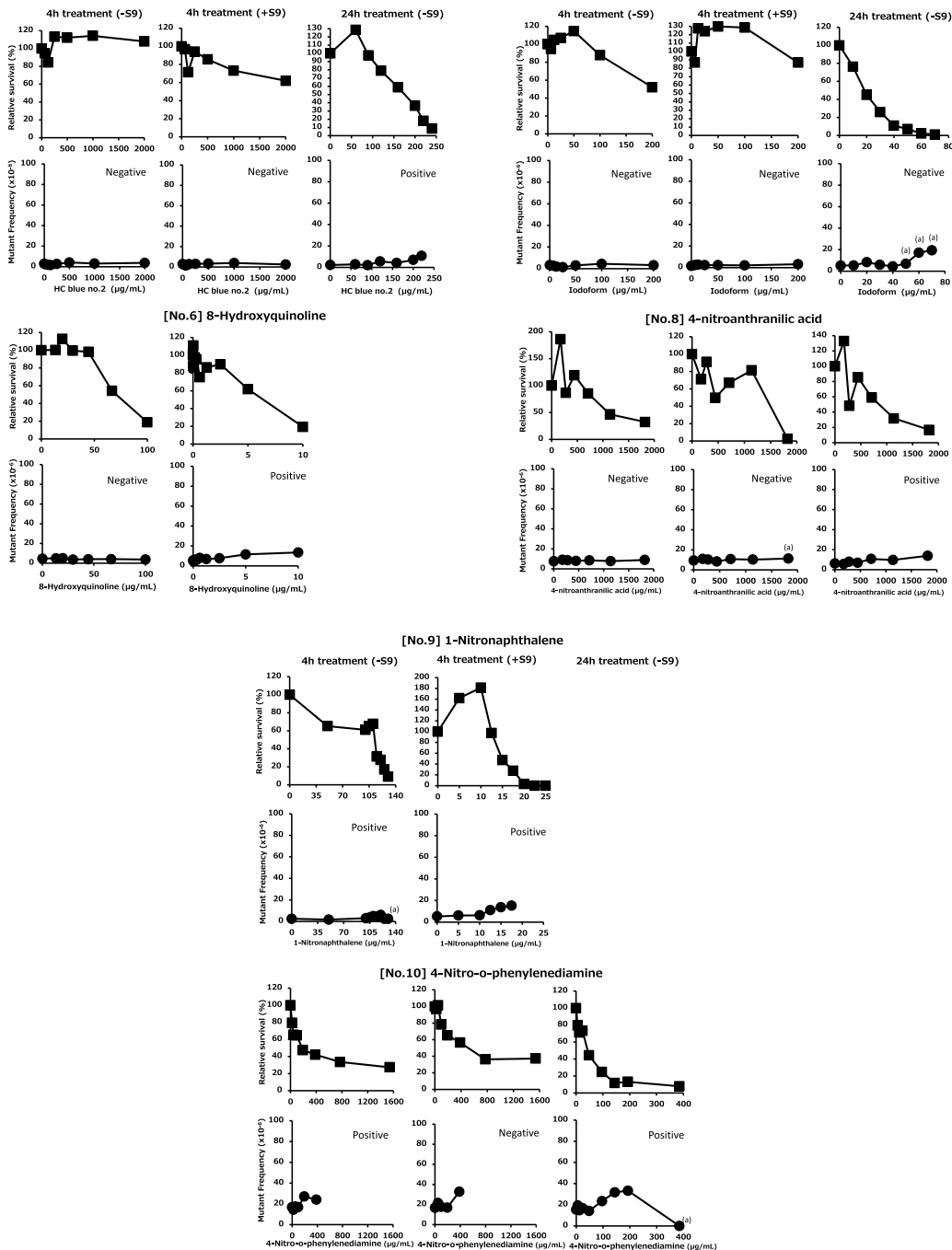

Fig. 1 (See legend on next page.) 
(See figure on previous page.)

Fig. 1 Relative survival and mutant frequency in TK6 assay for the 10 chemicals conducted by each laboratory. According to the OECD guidelines (TG490), dose finding tests were conducted before the main TK6 assays. The short- and long-term treatments were conducted for $4 \mathrm{~h}(+/-59 \mathrm{mix})$ and $24 \mathrm{~h}$ (-S9mix), respectively. The main tests were conducted so that the highest concentration was set at a concentration where the RS was from 10 to 20\%. Experiments and statistical analysis were conducted as described in Materials and Methods. (a) indicates the data of MF were excluded from the statistical judgment because RS was below $10 \%$

mutation frequency were not observed after the shortterm treatment in the absence or presence of metabolic activation and after the long-term treatment. Thus, 2,5diaminotoluene was judged to be negative.

\section{HC Blue No. 2}

Based on the results of the dose finding study, concentrations were determined. In the $4 \mathrm{~h}$ treatment with and without S9, $62.5-2000 \mu \mathrm{g} / \mathrm{mL}$ were selected. In the $24 \mathrm{~h}$ treatment without S9, 60-240 $\mu \mathrm{g} / \mathrm{mL}$ were selected. No precipitation was observed at any concentration in all groups. About $80 \%$ cytotoxicity was observed at $220 \mu \mathrm{g} /$ $\mathrm{mL}$ in the $24 \mathrm{~h}$ treatment without S9 and about $40 \%$ cytotoxicity was observed at $2000 \mu \mathrm{g} / \mathrm{mL}$ in $4 \mathrm{~h}$ treatment with S9. No cytotoxicity was observed in $4 \mathrm{~h}$ treatment without S9. There was no significant difference in MF after $4 \mathrm{~h}$ treatment with and without S9. After the $24 \mathrm{~h}$ treatment without S9, MF increased in a concentration-dependent manner as compared with that of the solvent control group and showed a statistically significant difference. $\mathrm{HC}$ Blue No. 2 was judged to have gene mutagenicity.

\section{8-Hydroxyquinoline}

After the short-term treatment (+S9), 8-Hydroxyquinoline showed cytotoxicity at the dose level of $10.0 \mu \mathrm{g} / \mathrm{mL}$, at which the RS was $19.3 \%$. Mutagenic responses to 8- hydroxyquinoline were significant in both Dunnett type test and linear trend tests with S9. After the short-term treatment (-S9), 8-hydroxyquinoline showed cytotoxicity at a dose level of $100 \mu \mathrm{g} / \mathrm{mL}$, at which the RS was $18.9 \%$. Mutagenic responses to 8-hydroxyquinoline were not significant in the Dunnett type test in without S9. Therefore, based on the above results, it was concluded that 8hydroxyquinoline had mutagenic potential in TK6 cells under the conditions of this study. Long-term treatment was not applied.

\section{lodoform}

After the $24 \mathrm{~h}$ treatment without S9, Iodoform showed cytotoxicity at the dose level of $40.0 \mu \mathrm{g} / \mathrm{mL}$, at which the RS was $10.9 \%$. Conversely, after $4 \mathrm{~h}$ treatment with/without S9, because of the strong toxicity during the expression period, mutation frequency at the concentration with RS of $10-20 \%$ could not be evaluated. Therefore, an additional study was conducted with treatment concentration at which RTG was $10-20 \%$ set as maximum concentration. Iodoform showed cytotoxicity at a dose level of $100(-S 9)$ and $200(+S 9) \mu \mathrm{g} / \mathrm{mL}$, at which the RTGs were 19.1 and $20.1 \%$, respectively. A dosedependent increase in MF was observed after the longterm treatment at the high-dose levels $(50-70 \mu \mathrm{g} / \mathrm{mL})$, which showed $\mathrm{RS}<10 \%$. These dose levels were

Table 3 Summary of results of TK gene mutation assay for the 10 chemicals

\begin{tabular}{|c|c|c|c|c|c|c|c|c|c|c|}
\hline \multirow[t]{2}{*}{ No. } & \multirow[t]{2}{*}{ Chemical Name } & \multirow[t]{2}{*}{ CAS No. } & \multicolumn{3}{|c|}{ TK mutation assay ${ }^{\mathrm{a}}$} & \multicolumn{2}{|c|}{$\begin{array}{l}\text { Bacterial reverse } \\
\text { mutation assay }\end{array}$} & \multicolumn{3}{|c|}{ MLA (TK gene locus) } \\
\hline & & & Without S9 & With S9 & Long term & Without S9 & With S9 & Without S9 & With S9 & Ref. \\
\hline 1 & 4-(Chloroacetyl)-acetanilide & $140-49-8$ & Pos & Neg & Pos & Neg & Pos & No data & & \\
\hline 2 & 2-(Chloromethyl) pyridine $\mathrm{HCl}$ & $6959-47-3$ & Pos & Pos & NP & Pos & Pos & Pos & Pos & [47] \\
\hline 3 & 2,6-Diaminotoluene & $823-40-5$ & Neg & Pos & Pos & Neg & Pos & Pos & No data & [48] \\
\hline 4 & 2,5-Diaminotoluene & $95-70-5$ & Neg & Neg & Neg & Neg & Pos & Inconclusive ${ }^{c}$ & & {$[46,49]$} \\
\hline 5 & HC Blue No.2 & $33229-34-4$ & Neg & Neg & Pos & Pos & Pos & Pos & Pos & [27] \\
\hline 6 & 8-Hydroxyquinoline & $148-24-3$ & Neg & Pos & NP & Neg & Pos & Pos & No data & {$[50]$} \\
\hline 7 & lodoform & $75-47-8$ & Neg & Neg & Neg & Pos & Pos & No data & & \\
\hline 8 & 4-Nitroanthranilic acid & $619-17-0$ & Neg & Neg & Pos & Pos & Pos & Equivocal $^{d}$ & Pos & [51] \\
\hline 9 & 1-Nitronaphthalene & $86-57-7$ & Pos & Pos & NP & Pos & Pos & No data & & \\
\hline 10 & 4-Nitro-o-phenylenediamine & $99-56-9$ & Pos & Neg & Pos & Pos & Pos & Pos & Pos & {$[52,53]$} \\
\hline
\end{tabular}

aPerformed in this study. NP Not applicated

${ }^{\mathrm{b}}$ Taken from Table 2

'Examined as toluene-2,5-diamine sulfate. The required toxicity (10-20\% survival compared to the concurrent negative controls) was not reached in the experiments with S9mix [46]

${ }^{\mathrm{d}}$ Significant difference only at the highest dose of $1200 \mu \mathrm{g} / \mathrm{mL}$ [51] 
excluded from the statistical judgment because of high cytotoxicity. MF values from 10 to $40 \mu \mathrm{g} / \mathrm{mL}$ were significant in the Dunnett modified test (Additional file 2 (Table S2)) but were not increased dose-dependently within the dose range. Hence, we suggest that the significant result obtained from the Dunnett modified test was not biologically relevant in this study. Therefore, the mutagenic potential of iodoform was negative as expert judgment.

\section{4-Nitroanthranilic acid}

More than 50\% cytotoxicity was observed at 1138 and $1821 \mu \mathrm{g} / \mathrm{mL}$ without metabolic activation, and approximately $100 \%$ cytotoxicity was observed at $1821 \mu \mathrm{g} / \mathrm{mL}$ with metabolic activation for the short-term treatment. More than $80 \%$ cytotoxicity was observed at $1821 \mu \mathrm{g} / \mathrm{mL}$ for the long-term treatment. There was no increase in mutation frequency after the short-term treatment with or without metabolic activation. A statistically significant increase in mutation frequency after the long-term treatment was observed.

\section{1-Nitronaphthalene}

Doses showing $80 \%$ cytotoxicity in the absence of S9 were between 120 and $125 \mu \mathrm{g} / \mathrm{mL}$. Doses showing 80\% cytotoxicity with S9 were between 17.5 and $20 \mu \mathrm{g} / \mathrm{mL}$. Regardless of metabolic activation and exposure time, a significant increase in MF was observed under the condition used in this study. Long-term treatment was not applied. Hence, this test chemical, 1-nitronaphthalene, was judged as positive.

\section{4-Nitro-o-phenylenediamine}

More than $80 \%$ cytotoxicity was observed at $144 \mu \mathrm{g} / \mathrm{mL}$ and above for the long-term treatment. MF was increased significantly in the statistical analysis compared with the negative control value for short-term (-S9) and long-term assays. The judgment for this chemical was positive. Cells exposed to 770 and $1540 \mu \mathrm{g} / \mathrm{mL}(+/-S 9)$ were abandoned because of high cytotoxicity.

\section{Proteomics analysis}

A total of 1078 DEPs $(4 \mathrm{~h} 400 \mu \mathrm{g} / \mathrm{mL}$ group: 359 proteins, $4 \mathrm{~h} 800 \mu \mathrm{g} / \mathrm{mL}$ group: 506 proteins, $24 \mathrm{~h} 400 \mu \mathrm{g} /$ $\mathrm{mL}$ group: 358 proteins, and $24 \mathrm{~h} 800 \mu \mathrm{g} / \mathrm{mL}$ group: 420 proteins) were identified based on $\log _{2}$ fold change of $\geq 2$ (Fig. 2a). Furthermore, 168 specific DEPs in the $24 \mathrm{~h}$ $800 \mu \mathrm{g} / \mathrm{mL}$ group were extracted from 420 DEPs in $24 \mathrm{~h}$ $800 \mu \mathrm{g} / \mathrm{mL}$ group based on a $\log _{2}$ fold change between $24 \mathrm{~h} 800 \mu \mathrm{g} / \mathrm{mL}$ group and other groups $\geq 1$ (Fig. $2 \mathrm{~b}$ ).

In the analysis of specific DEPs in $24 \mathrm{~h} 800 \mu \mathrm{g} / \mathrm{mL}$ group, the enrichment analysis of upregulated proteins revealed that the expression level of proteins that associated with transcription, cellular stress and cell division was remarkably upregulated (e.g., GO:0034244 negative regulation of transcription elongation from RNA polymerase II promoter, GO:0008631 intrinsic apoptotic signaling pathway in response to oxidative stress, GO:0051301 cell division, and GO:2000145 regulation of cell motility) (Table 4A). Furthermore, the analysis of downregulated proteins revealed proteins related to rRNA processing and cell division (e.g., GO:0000462 $\sim$ maturation of SSU-rRNA from tricistronic rRNA transcript (SSU-rRNA, 5.8S rRNA, and LSU-rRNA) and GO: $0051301 \sim$ cell division).

In the target analysis of specific GO term among groups (Fig. 3), $P$-values of GO:0006974 (cellular response to DNA damage stimulus), GO:0006979 (response to oxidative stress), and GO:0006281 (DNA repair) were less than 0.05 , indicating no significant difference. Conversely, enrichment scores (-log ( $p$-value)) of GO:0008631 intrinsic apoptotic signaling pathway in response to oxidative stress were drastically increased in DEPs in $24 \mathrm{~h} 800 \mu \mathrm{g} /$ $\mathrm{mL}$ group and specific DEPs in $24 \mathrm{~h} 800 \mu \mathrm{g} / \mathrm{mL}$ group, indicating involvement with oxidative stress.

In DEPs in $24 \mathrm{~h} 800 \mu \mathrm{g} / \mathrm{mL}$ group, three proteins ([Pyruvate dehydrogenase (acetyl-transferring)] kinase isozyme 1 , mitochondrial phosphoinositide-dependent kinase 1: PDK1, superoxide dismutase 2, mitochondrial: SOD2, direct IAP-binding protein with low PI: DIABLO) that belong to GO:0008631 intrinsic apoptotic signaling pathway in response to oxidative stress were included (Figs. 3 and 4). The expression level of these proteins is elevated only after the $24 \mathrm{~h}$ treatment. Furthermore, the expression level of SOD2 was elevated dose-dependently, and PDK1 and DIABLO were only elevated at $800 \mu \mathrm{g} / \mathrm{mL}$.

\section{Discussion}

\section{Usefulness of the TK6 assay as a follow-up for testing Ames-positive compounds}

The 10 test substances used in this collaborative study were mostly polycyclic aromatic compounds containing amino groups or nitro groups. Characteristics of chemical structures were examined for any regularity or correlation with the results of TK6 assays. The assay can certainly be positive for 8-hydroxyquinoline, 1-nitronaphthalene, and 4-nitro-o-phenylenediamine with specific activity values exceeding 10,000 revertants per milligram obtained from Ames test, even three compounds (4-(chloroacetyl)-acetanilide, 2-(chloromethyl) pyridine $\mathrm{HCl}$, and $\mathrm{HC}$ Blue No. 2 ) with small specific activity values of several hundred revertants per milligram were detected as positive (Tables 2 and 3). Thus, the results of TK6 assays are not related to the strength of the specific activity value of the Ames test. Based on our results obtained in the present study, no regularity could be found between mutagenicity results and chemical structures of test substances. 
(A)
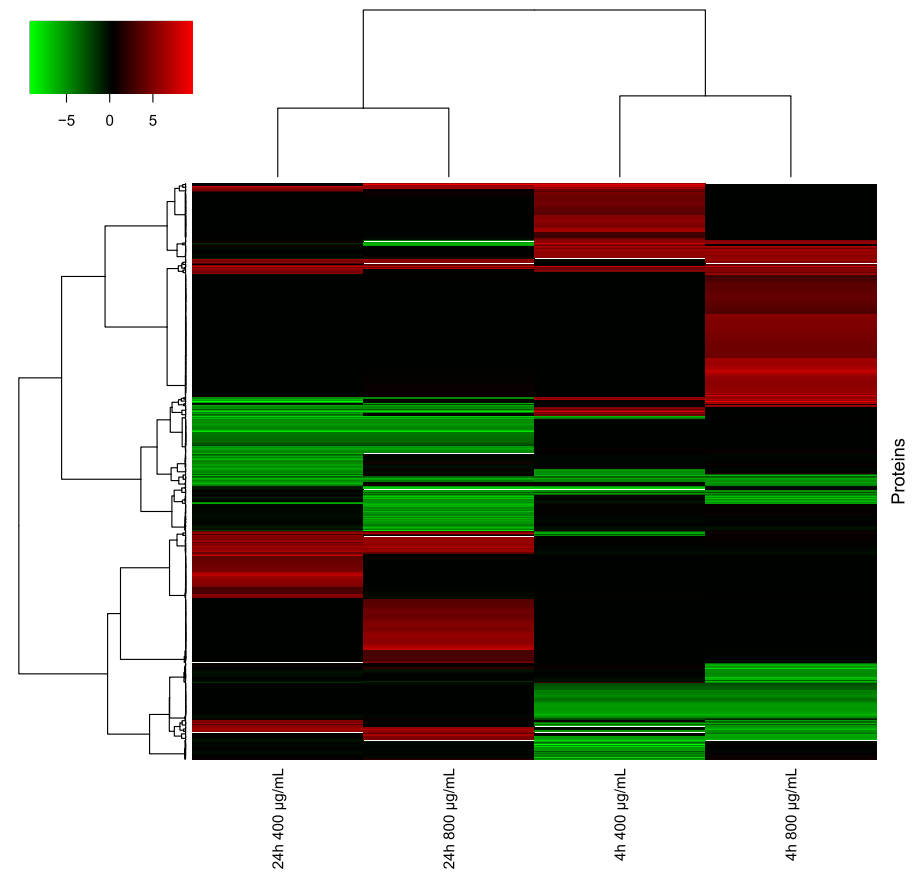

(B)
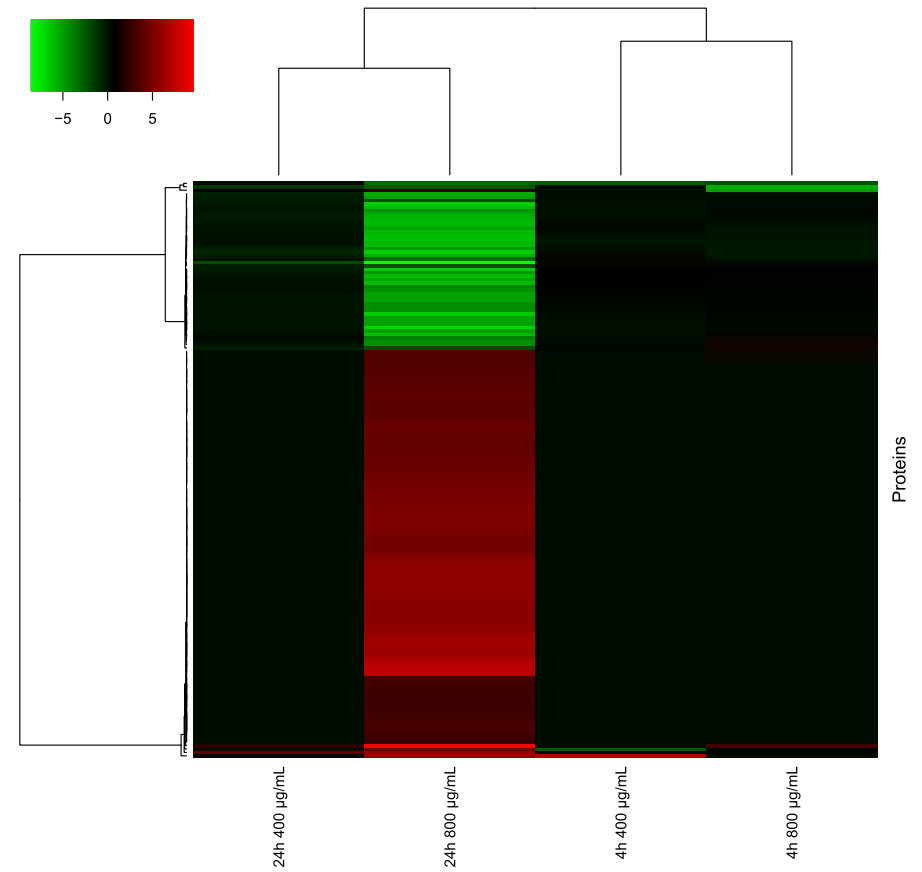

Fig. 2 Differentially expressed proteins (DEP) identified in TK6 cells exposed to 4-nitroanthranilic acid. a A total of 1078 DEPs that differentially expressed compared to control groups were identified based on a $\log _{2}$ fold change of $\geq 2$. Effects of treatment time are greater than that of dose. $\mathbf{b}$ A total of 168 specific DEPs that differentially expressed compared to other groups were further extracted from the $420 \mathrm{DEPs}$ in $24 \mathrm{~h} 800 \mathrm{\mu g} / \mathrm{mL}$ group based on a $\log _{2}$ fold change of $\geq 1$

The TK6 assay showed that two substances, 2,5-diaminotoluene and iodoform, were negative (20\% effective as a follow-up test), and the remaining eight substances were positive (Table 3). Seven of these substances were reported by MLA using L5178Y cells (Table 3), and all seven showed positive results, including an "inconclusive" judgment for 2,5-diaminotoluene that was reported negative and positive by the Scientific Committee on Consumer Safety (SCCS) [46] and the National Toxicology Program (NTP) database [54], respectively. Compared to p53proficient TK6 cells, p53-deficient L5178Y cells are 
Table 4 Enrichment analysis of 168 specific DEPs in the tretment of 4-nitroanthranilic acid (24-h $800 \mu \mathrm{g} / \mathrm{mL}$ group)

\begin{tabular}{|c|c|c|c|}
\hline Category & Term & Count & PValue \\
\hline \multicolumn{4}{|l|}{ A) Up-regulated proteins } \\
\hline INTERPRO & IPR016239:Ribosomal protein S6 kinase II & 4 & 5.74E-06 \\
\hline GOTERM_MF_DIRECT & GO:0005515 protein binding & 88 & $1.74 \mathrm{E}-05$ \\
\hline PIR_SUPERFAMILY & PIRSF000606:ribosomal protein S6 kinase ॥ & 4 & $3.22 \mathrm{E}-05$ \\
\hline GOTERM_MF_DIRECT & GO:0016301 kinase activity & 10 & $6.80 \mathrm{E}-05$ \\
\hline GOTERM_CC_DIRECT & GO:0005739 mitochondrion & 22 & $2.16 \mathrm{E}-04$ \\
\hline SMART & SM00133:S_TK_X & 5 & $3.29 \mathrm{E}-04$ \\
\hline GOTERM_CC_DIRECT & GO:0005829 cytosol & 39 & 4.31E-04 \\
\hline INTERPRO & IPR000961:AGC-kinase, C-terminal & 5 & $5.33 \mathrm{E}-04$ \\
\hline GOTERM_CC_DIRECT & GO:0005654 nucleoplasm & 34 & $6.58 \mathrm{E}-04$ \\
\hline INTERPRO & IPR017892:Protein kinase, C-terminal & 4 & 0.0010359705 \\
\hline GOTERM_CC_DIRECT & GO:0005759 mitochondrial matrix & 9 & 0.0017034795 \\
\hline GOTERM_BP_DIRECT & $\begin{array}{l}\text { GO:0034244 negative regulation of transcription } \\
\text { elongation from RNA polymerase II promoter }\end{array}$ & 3 & 0.0027144316 \\
\hline GOTERM_CC_DIRECT & GO:0005737 cytoplasm & 51 & 0.0027796207 \\
\hline GOTERM_BP_DIRECT & $\begin{array}{l}\text { GO:0008631 intrinsic apoptotic signaling pathway in } \\
\text { response to oxidative stress }\end{array}$ & 3 & 0.0050854061 \\
\hline GOTERM_CC_DIRECT & GO:0005840 ribosome & 6 & 0.0053822808 \\
\hline GOTERM_MF_DIRECT & GO:0044822 poly(A) RNA binding & 17 & 0.0078806589 \\
\hline GOTERM_CC_DIRECT & GO:0005743 mitochondrial inner membrane & 9 & 0.0101302596 \\
\hline GOTERM_CC_DIRECT & $\begin{array}{l}\text { GO:0005793 endoplasmic reticulum-Golgi intermediate } \\
\text { compartment }\end{array}$ & 4 & 0.0109324145 \\
\hline GOTERM_BP_DIRECT & GO:0001701 in utero embryonic development & 6 & 0.011424021 \\
\hline GOTERM_CC_DIRECT & GO:0016020 membrane & 25 & 0.0115217146 \\
\hline GOTERM_MF_DIRECT & GO:0005524 ATP binding & 20 & 0.0117814813 \\
\hline GOTERM_BP_DIRECT & GO:0010628 positive regulation of gene expression & 7 & 0.0117937932 \\
\hline GOTERM_BP_DIRECT & GO:0051301 cell division & 8 & 0.0134335953 \\
\hline GOTERM_BP_DIRECT & GO:0043555 regulation of translation in response to stress & 2 & 0.0143601269 \\
\hline INTERPRO & IPR027417:P-loop containing nucleoside triphosphate hydrolase & 13 & 0.0146424367 \\
\hline GOTERM_MF_DIRECT & GO:0004672 protein kinase activity & 8 & 0.0161283188 \\
\hline GOTERM_MF_DIRECT & GO:0000287 magnesium ion binding & 6 & 0.0168341212 \\
\hline GOTERM_BP_DIRECT & GO:2000145 regulation of cell motility & 3 & 0.0172254639 \\
\hline INTERPRO & IPR018199:Ribosomal protein S4e, N-terminal, conserved site & 2 & 0.0199116243 \\
\hline INTERPRO & IPR013845:Ribosomal protein S4e, central region & 2 & 0.0199116243 \\
\hline INTERPRO & IPR013843:Ribosomal protein S4e, N-terminal & 2 & 0.0199116243 \\
\hline INTERPRO & IPR000876:Ribosomal protein S4e & 2 & 0.0199116243 \\
\hline INTERPRO & IPR000633:Vinculin, conserved site & 2 & 0.0199116243 \\
\hline GOTERM_BP_DIRECT & $\begin{array}{l}\text { GO:0006368 transcription elongation from } \\
\text { RNA polymerase II promoter }\end{array}$ & 4 & 0.0242278191 \\
\hline INTERPRO & IPR001033:Alpha-catenin & 2 & 0.0264610401 \\
\hline INTERPRO & IPR023321:PINIT domain & 2 & 0.0264610401 \\
\hline GOTERM_CC_DIRECT & GO:0032021 NELF complex & 2 & 0.0267274499 \\
\hline GOTERM_MF_DIRECT & GO:0048487 beta-tubulin binding & 3 & 0.0282329504 \\
\hline GOTERM_BP_DIRECT & GO:0019673 GDP-mannose metabolic process & 2 & 0.0285157205 \\
\hline SMART & SM00220:S_TKc & 7 & 0.0318734045 \\
\hline
\end{tabular}


Table 4 Enrichment analysis of 168 specific DEPs in the tretment of 4-nitroanthranilic acid (24-h $800 \mu \mathrm{g} / \mathrm{mL}$ group) (Continued)

\begin{tabular}{|c|c|c|c|}
\hline Category & Term & Count & PValue \\
\hline GOTERM_BP_DIRECT & GO:0030521 androgen receptor signaling pathway & 3 & 0.0351748989 \\
\hline GOTERM_MF_DIRECT & GO:0061665 SUMO ligase activity & 2 & 0.0359086364 \\
\hline PIR_SUPERFAMILY & PIRSF002116:ribosomal protein S4a/S4e & 2 & 0.0367953139 \\
\hline INTERPRO & IPR002942:RNA-binding S4 domain & 2 & 0.03942991 \\
\hline GOTERM_CC_DIRECT & GO:0022627 cytosolic small ribosomal subunit & 3 & 0.0416602582 \\
\hline GOTERM_BP_DIRECT & $\begin{array}{l}\text { GO:0043620 regulation of DNA-templated } \\
\text { transcription in response to stress }\end{array}$ & 2 & 0.0424696701 \\
\hline GOTERM_BP_DIRECT & GO:0046939 nucleotide phosphorylation & 2 & 0.0424696701 \\
\hline INTERPRO & IPR017441:Protein kinase, ATP binding site & 7 & 0.0427994892 \\
\hline GOTERM_BP_DIRECT & GO:0007507 heart development & 5 & 0.0434212707 \\
\hline GOTERM_MF_DIRECT & GO:0016887 ATPase activity & 5 & 0.0449232427 \\
\hline INTERPRO & IPR000719:Protein kinase, catalytic domain & 8 & 0.0450805987 \\
\hline INTERPRO & IPR006077:Vinculin/alpha-catenin & 2 & 0.0458499332 \\
\hline INTERPRO & IPR004181:Zinc finger, MIZ-type & 2 & 0.0458499332 \\
\hline GOTERM_MF_DIRECT & GO:0003723 RNA binding & 9 & 0.0467405365 \\
\hline \multicolumn{4}{|c|}{ B) Down-regulated proteins } \\
\hline GOTERM_CC_DIRECT & GO:0005730 nucleolus & 13 & $5.68 \mathrm{E}-07$ \\
\hline GOTERM_MF_DIRECT & GO:0044822 poly(A) RNA binding & 15 & $7.76 \mathrm{E}-07$ \\
\hline GOTERM_BP_DIRECT & GO:0006364 rRNA processing & 7 & $1.24 \mathrm{E}-05$ \\
\hline GOTERM_CC_DIRECT & GO:0005634 nucleus & 27 & 4.81E-05 \\
\hline GOTERM_CC_DIRECT & GO:0032040 small-subunit processome & 4 & $8.14 \mathrm{E}-05$ \\
\hline GOTERM_CC_DIRECT & GO:0005737 cytoplasm & 25 & 2.75E-04 \\
\hline GOTERM_CC_DIRECT & GO:0005654 nucleoplasm & 17 & 4.87E-04 \\
\hline GOTERM_BP_DIRECT & $\begin{array}{l}\text { GO:0000462 maturation of SSU-rRNA from } \\
\text { tricistronic rRNA transcript (SSU-rRNA, 5.8S } \\
\text { rRNA, LSU-rRNA) }\end{array}$ & 3 & 0.0027542237 \\
\hline GOTERM_MF_DIRECT & GO:0005515 protein binding & 34 & 0.0028754728 \\
\hline INTERPRO & IPR006709:Small-subunit processome, Utp14 & 2 & 0.0049511535 \\
\hline GOTERM_CC_DIRECT & GO:0005815 microtubule organizing center & 4 & 0.0059735276 \\
\hline GOTERM_BP_DIRECT & GO:0051301 cell division & 5 & 0.0102371094 \\
\hline GOTERM_CC_DIRECT & $\begin{array}{l}\text { GO:0034388 Pwp2p-containing subcomplex } \\
\text { of } 90 \text { S preribosome }\end{array}$ & 2 & 0.0167816086 \\
\hline GOTERM_BP_DIRECT & $\begin{array}{l}\text { GO:0002726 positive regulation of T cell } \\
\text { cytokine production }\end{array}$ & 2 & 0.0241562593 \\
\hline GOTERM_CC_DIRECT & GO:0070062 extracellular exosome & 13 & 0.0308651552 \\
\hline GOTERM_BP_DIRECT & GO:0030490 maturation of SSU-rRNA & 2 & 0.0336585264 \\
\hline INTERPRO & IPR017986:WD40-repeat-containing domain & 4 & 0.0400340949 \\
\hline GOTERM_BP_DIRECT & GO:0022904 respiratory electron transport chain & 2 & 0.0477428897 \\
\hline INTERPRO & IPR015943:WD40/YVTN repeat-like-containing domain & 4 & 0.0486054435 \\
\hline
\end{tabular}

more sensitive to spindle inhibitors due to disruption of spindle checkpoints and apoptosis [55]. Moreover, Whitwell et al. reported that the use of human TK6 cells may be preferable over rodent L5178Y cells to help reduce false positive results in in vitro assay [56]. We believe that the TK6 assay, due to negative here for 2,5-diaminotoluene in this study, may indicate a possible improvement over MLA to help follow-up on false-positive results from Ames testing.

In general, it is difficult to follow up the positive results of the Ames test, which detects DNA-reactive substances, with in vitro mammalian cell gene mutation test, as it may lead to similar results to the Ames test in terms of the principle of detecting mutations 

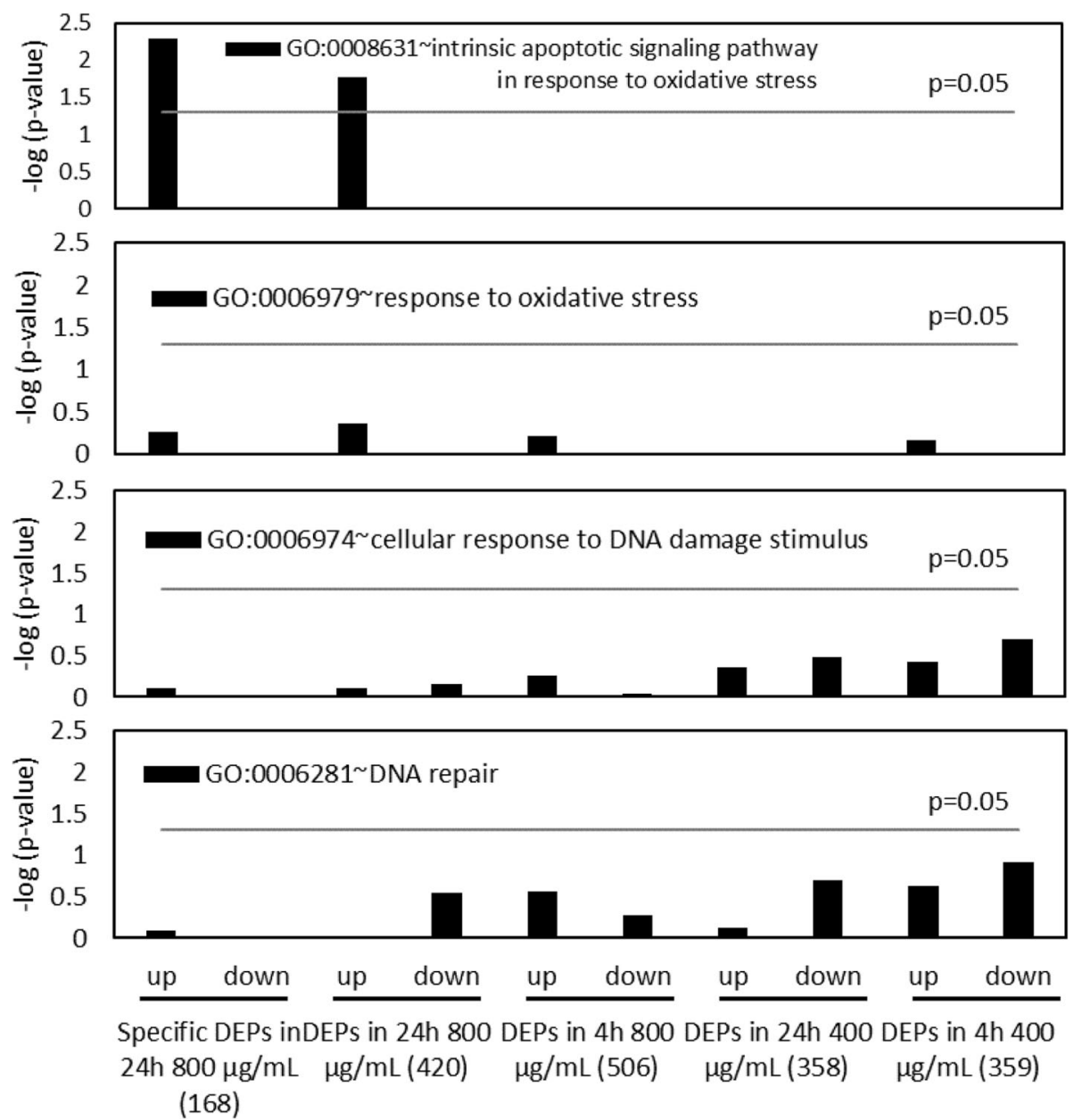

Fig. 3 Target gene ontology analysis for TK6 cells exposed to 4-nitroanthranilic acid for $24 \mathrm{~h}$. Whereas no significance was found in G0:0006974 (cellular response to DNA damage stimulus), GO:0006281 (DNA repair), and GO:0006979 (response to oxidative stress), statistically significance was found in GO:0008631 intrinsic apoptotic signaling pathway in response to oxidative stress among DEPs in $24 \mathrm{~h} 800 \mu \mathrm{g} / \mathrm{mL}$ group and specific DEPs in $24 \mathrm{~h} 800 \mathrm{\mu g} / \mathrm{mL}$ group, indicating involvement with oxidative stress

$[4,57]$. In this present study, $20 \%$ effective ( 2 negative results of 10 substances in the TK6 assay) suggests that the TK6 assay may be able to follow up on the positive results of the Ames test. Six substances (4(chloroacetyl)-acetanilide, 2-(chloromethyl) pyridine $\mathrm{HCl}$, 2,6-diaminotoluene, 8-hydroxyquinoline, 1nitronaphthalene, and 4-nitro-o-phenylenediamine) that are negative in in vivo genotoxicity tests (chromosomal Aberration test, micronucleus test, and transgenic rodent gene mutation assay) are not considered to be carcinogenic [48, 58-63], because their genotoxicity is eliminated by biological reactions (e.g., ADME; absorption, distribution, metabolism and excretion) even if they show DNA reactivity in vitro such as TK6 assay. Thus, Ames-positive substances, such as 2,5-diaminotoluene, that are negative in the TK6 assay, not via ADME, and negative in the in vivo test may have bacterial-specific DNA reactivity. Kirkland et al. [14, 15] reported that, in the case of an Ames-positive chemical, negative results in two in vitro mammalian cell tests covering both mutation and clastogenicity/aneugenicity endpoints should be considered as indicative of absence of in vivo genotoxic or carcinogenic potential. As the mutation endpoint, the human TK6 assay, even by current methods that have not been combined with new technologies such as proteomics, may have sufficient potential to reduce some false positive results (20\%) as a follow-up test.

Possible mechanisms of chemical mutagenesis involving reactive oxygen species (ROS) production in the longterm treatment with TK6 cells

Interestingly, three (2,6-diaminotoluene, HC Blue No. 2, and 4-nitroanthranilic acid) of the eight positive substances in the present study were negative after the 


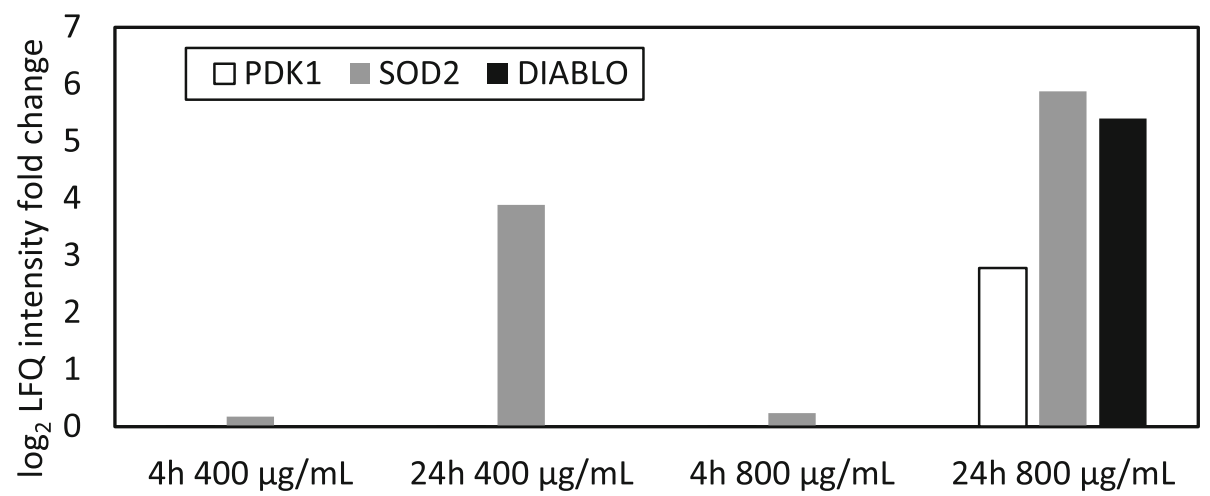

Fig. 4 Protein expression levels of the intrinsic apoptotic signaling pathway in response to oxidative stress by the $24 \mathrm{~h}$ treatment of 4 -nitroanthranilic acid. PDK1, SOD2, DIABLO that belong to GO:0008631 intrinsic apoptotic signaling pathway in response to oxidative stress were drastically elevated only at the $24 \mathrm{~h}$ treatment of 4-nitroanthranilic acid, especially in the $800 \mu \mathrm{g} / \mathrm{mL}$ group

short-term treatment and positive after the $24 \mathrm{~h}$ treatment (Table 3), despite identical treatment conditions in the absence of S9. Thus, an extended treatment time of only $20 \mathrm{~h}$ long, the judgment of these substances was changed from negative to positive (Table 3). Based on the chemical structures of these three compounds, we discussed the mechanisms of positives results after the long-term treatment in the absence of S9.

\section{2,6-Diaminotoluene}

Metabolism of hepatic microsomes in general (such as +S9) oxidize arylamines to hydroxylamines by $\mathrm{P} 450$ and $\mathrm{O}$-acetylized to acetoxyarylamines with acetyltransferase. These further break down spontaneously into arylnitrenium ions that form adducts with bases in nucleic acids $[64,65]$. Additionally, arylamines are metabolized to hydroxylamines with amine $N$-oxidase and flavincontaining monooxygenase (FMO) [66]. Mutagenicity was confirmed in human TK6 cells after $96 \mathrm{~h}$ of exposure to benzidine, one of the arylamines, in the absence of S9 [67]. Additionally, the mutagenicity of 2,6-diaminotoluene occurs in MLA using L5178Y mouse lymphoma cells $(4 \mathrm{~h},-\mathrm{S} 9)$ [68]. A slight expression of P450 has been reported in TK6 cells [69]. In the present study, the enzyme expression for P450s, amine $\mathrm{N}$-oxidase, and FMO was not detected; however, the formation of proteins related to $\mathrm{O}$-acetylization ( $\mathrm{N}$-acetyltransferase) was measured in the proteomic analysis of vehicle TK6 control (Additional file 3 (Table S3)). These findings suggest the possibility of DNA adduct formation by arylnitrenium ions via oxidation of arylamine with some enzymes in TK6 cells (24h, - S9) [65]. Furthermore, the induction of DNA damage mediated by ROS is highly plausible (Fig. 5) [65, 70-72].

2,4-Diaminotoluene and 2,6-diaminotoluene are considered carcinogenic and non-carcinogenic, respectively, based on a report of the National Toxicology Program
(NTP), USA [24], although one study indicated that it is not at all clear that 2,6-diaminotoluene is noncarcinogenic [73]. Significant DNA adducts were detected in the livers of rats exposed to 2,4-diaminotoluene; otherwise, a marginal amount of adducts was detected in the case 2,6-diaminotoluene [74]. In studies on the comparison with 2,4-diaminotoluene, negative results for 2,6-diaminotoluene with respect to hepatocellular proliferation in rats [75], an unscheduled DNA synthesis (UDS) assay in rats [76], a mutagenic assay with LacI transgenic mice [77], and a guaninehypoxanthine phosphoribosyltransferase $(g p t)$ mutagenic assay with transgenic rats $[23,78]$ have been reported, although positive results were also confirmed at a high dose of 2,6-diaminotoluene via a UDS assay [79]. Furthermore, the negative result was confirmed by a comet assay of various mouse organs [80]. 2,6-Diaminotoluene might be more efficiently detoxified than 2,4-diaminotoluene in vivo because its para site at position 4 can be oxidized and subsequently conjugated by phase II enzymes [81]. The formation of the DNA adduct via the nitrenium ion is important for the Ames assay, and it has been reported that the mutagenicity $(+S 9)$ of 2,5 -diaminotoluene is lower than that of 2,6-diaminotoluene [82]. In the present study, the results showed that 2,5diaminotoluene was not mutagenic and 2,6-diaminotoluene was mutagenic according to the TK assay in the 4$\mathrm{h}$ treatment with S9 and in the 24-h treatment without S9, which was assumed to affect the formation of the DNA adducts via the arylnitrenium ion.

ROS are formed and mediated by oxidation to quinonediimines in keratinocytes, in which the expression of oxidative enzymes is minimal for arylamines [70]. Additionally, ROS are formed via hydroxylamines and aminophenols, which are P450-mediated oxidative metabolites for arylamines $[65,71,72]$. For arylamines such as 2 , 6-dimethylaniline and 3,5-dimethylaniline, the principal 


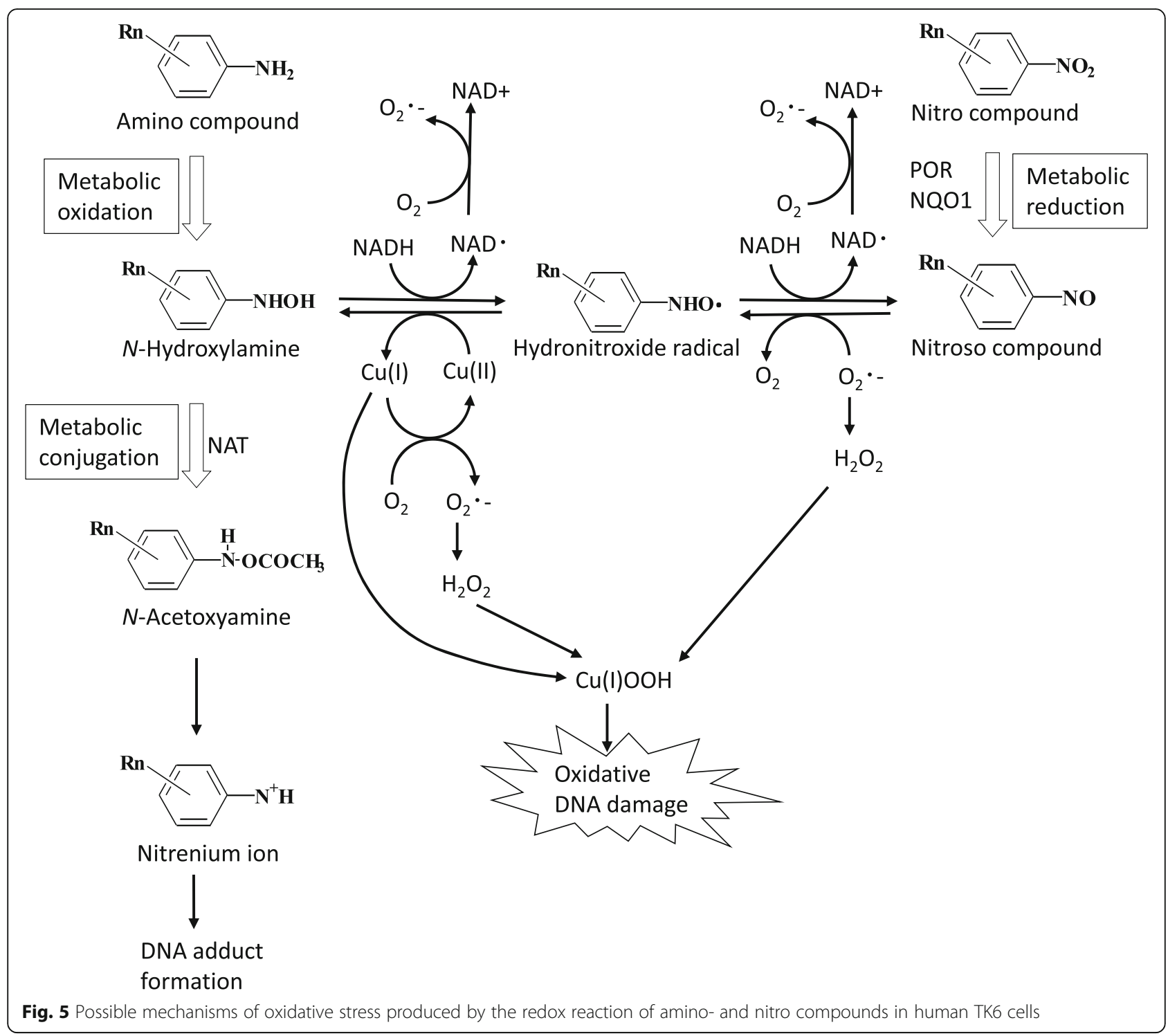

mechanism of mutagenic action is likely associated with aminophenol/quinone imine redox cycling to generate ROS rather than the formation of covalent DNA adducts via the arylnitrenium ion [71, 72]. 2,6-diaminoltoluene may be metabolized in the same pathway as arylamines. Metabolites of 2,6-diaminoltoluene that contribute to ROS formation and accumulation are unknown.

\section{HC Blue No. 2}

Nitro compounds are reduced to hydroxylamines with nitroreductases, such as $\mathrm{NAD}(\mathrm{P}) \mathrm{H}$ quinone oxidoreductase (NQO1) and P450 oxidoreductase (POR), and are $\mathrm{O}$-acetylized to acetoxyarylamines with acetyltransferase. These metabolites break down spontaneously into arylnitrenium ions that form adducts with bases in nucleic acids $[64,65]$. NQO1 is expressed in TK6 in the normal state [83], and the proteomics analysis in the present study, measured nitroreductases, such as NQO1 and POR, and proteins related to $\mathrm{O}$-acetylization ( $\mathrm{N}$-acetyltransferase) in the vehicle TK6 control (Additional file 3 (Table S3)). DNA adduct formation via the arylnitrenium ion and ROS formation via hydroxylamine likely contribute to DNA damage caused by HC Blue No. 2 in TK6 cells after $24 \mathrm{~h}$ of exposure in the absence of S9 (Fig. 5) [65].

HC blue No. 1 has been determined to be a carcinogen, whereas HC blue No.2 has been classified as a noncarcinogenic. However, reinterpretation of bioassays showed that the results did not justify HC blue No. 2 being classified as a carcinogenic or as definitely a noncarcinogenic [84]. The MLA ( $4 \mathrm{~h}$ ) for HC blue No. 2 was positive in the presence of $S 9[27,29,68]$, and the mutagenicity in MLA (+S9) for carcinogenic HC blue No. 1 has also been reported to be positive with weak response 
[68]. Meanwhile, a negative result has been reported for carcinogenic $\mathrm{HC}$ blue No. 1 with high purity in MLA (-S9) and other mutagenic assays [27, 85]. For HC blue No. 2 with high purity, a positive result was obtained in MLA (-S9) though the evaluation of carcinogenicity has not been reported [27]. The differences between in vitro and in vivo metabolites may be responsible for the different results of $\mathrm{HC}$ blue No. 1 related to mutagenicity (negative in the absence of S9) and carcinogenicity (carcinogenic) [27]. The in vivo metabolite of HC blue No. 2 was single, and the non-carcinogenic result of $\mathrm{HC}$ blue No. 2 in animal experiments may be due to the conjugation and the excretion of the metabolite [27].

\section{4-Nitroanthranilic acid}

This chemical possesses three functional groups: nitro, amino, and carboxyl. However, it is presumably metabolized and excreted relatively quickly because of the carboxyl group. Therefore, a negative result of chemical in TK6 assays $(4 \mathrm{~h},+\mathrm{S} 9)$ in the present study was likely due to the facilitation of its oxidative metabolism. Furthermore, 4-nitroanthranilic acid showed a negative result upon exposure for $4 \mathrm{~h}$ and a positive result after $24 \mathrm{~h}$ in the absence of S9. DNA damage was likely induced by the arylnitrenium ion and ROS via the reductive metabolism of the nitro group that required longer time frames $24 \mathrm{~h}$ (Fig. 5). Major oxidative enzymes that act on amino groups, such as $\mathrm{P} 450 \mathrm{~s}$, amine $\mathrm{N}$-oxidase, and FMO, were not confirmed, and nitro reductive enzymes, such as NQO1 and POR, were detected via proteomic analysis of TK6 control cells (Additional file 3 (Table S3)) $[65,69,83]$.

\section{Oxidative stress revealed by proteomics analysis}

The enrichment analysis of DEPs in the $24 \mathrm{~h}$ treatment condition suggested that oxidative stress plays a key role in the enhancement of cytotoxicity and genotoxicity in continuous exposure conditions (Fig. 4). PDK1, SOD2, and DIABLO were expressed prominently after a $24 \mathrm{~h}$ exposure of cells to $800 \mu \mathrm{g} / \mathrm{mL}$ 4-nitroanthranilic acid in the present study. These proteins are all involved in response to oxidative stress. A dose- and time-dependent increasing tendency of major antioxidant enzymes (catalase and GSR) was confirmed in the proteomics analysis (Additional file 3 (Table S3) and 4 (Figure S1)). After the short-term treatment, antioxidant defenses such as glutathione and related enzymes in TK6 cells were able to suppress ROS damage, but with the long-term treatment, the increase of oxidative stress caused by depletion of antioxidant enzymes is expected. The prominent decrease of several antioxidant enzymes (GPX4, MGST3, TXN2, TXNRD1, etc.) at $24 \mathrm{~h}$ in contrast to $4 \mathrm{~h}$ in the proteomics analysis may reflect such depletion (Additional file 3 (Table S3) and 4 (Figure S1)). Additionally, oxidative stress has been considered as a common underlying mechanism for in vitro specific genotoxicity. Generally, mammalian tissues in vivo are likely to display greater antioxidant defenses than cells in culture. Chemicals that induce genotoxicity via the production of ROS, in such case, would damage DNA directly but would be expected to have a threshold [86]. Further analyses are needed to confirm whether these same features of DEPs are observed in other chemicals with conflicting test results. If the same features are observed, quantification of these proteins (or genes) or ROS would provide a promising solution to discriminating in vitro specific positive results from a mode of action point of view.

\section{Conclusions}

The usefulness of the TK6 assay, by current methods that have not been combined with new technologies such as proteomics, was found to be limited as a followup test, although it still may help to reduce some false positive results (20\%) in Ames tests. Furthermore, in vitro specific genotoxicity was prominently exhibited in the long-term treatment, but proteomics analysis of a false-positive compound revealed a mode of action, in which genotoxicity caused was induced by oxidative stress during the long-term treatment. Therefore, an integration of omics technology and TK6 assays may contribute to interpreting irregular results in $24 \mathrm{~h}$ specific positives and might lead to further reduction (>20\%) of false positives in follow-up to Ames tests.

\section{Supplementary Information}

The online version contains supplementary material available at https://doi. org/10.1186/s41021-021-00179-1

\section{Additional file 1.}

Additional file 2

Additional file 3.

Additional file 4

\section{Abbreviations}

TK6 assay: Thymidine kinase gene mutation assay; WoE: Weight of evidence; JEMS: The Japanese Environmental Mutagen Society; MMS: The Mammalian Mutagenicity Study group; OECD: The Organization for Economic Cooperation and Development; AOP: Adverse outcome pathway; IATA: Integrated approaches to testing and assessment; SCCS: Scientific Committee on Consumer Safety; MLA: Mouse lymphoma assay; CE: Cloning efficiency; RS: Relative survival; RSG: Relative suspension growth; RTG: Relative total growth; MF: Mutant frequency; LFQ: Label-free quantification; TCEP: Tris (2-carboxyethyl)phosphine; NaN: Not a number; DEP: Differentially expressed protein; GO: Gene Ontology

\section{Acknowledgments}

The authors are grateful to Dr. Mariko Murata (Department of Environmental and Molecular Medicine, Mie University) for helpful comments and supporting the figure preparation. The authors would like to thank Enago (www.enago.com) for the English language review. 


\section{Authors' contributions}

$\mathrm{MY}, \mathrm{KO}$, and $\mathrm{MH}$ designed the research. MY, TF, AU, TI, TH, HY, KS, KN, YF, EO, $S F, M Y, N O, M N, R N, M U, M M, K M, A T, K T, Y O, M N, S H$, and $A K$ conducted the experiments and analyzed the data in TK6 assay. MY, TF, RN, and JM managed the data files in the collaborative study. MY, HH, JA, and KM conducted the experiments and analyzed the data in toxicoproteomics. MY, TF, HH, and KM drafted the manuscript, and the remaining authors reviewed and revised the manuscript. All authors read and approved the final manuscript.

\section{Funding}

This study was supported by a Grant-in-Aid for Scientific Research from the Ministry of Health, Labor and Welfare (H30-Food-General-003).

\section{Availability of data and materials}

Not applicable.

\section{Ethics approval and consent to participate}

Not applicable.

\section{Consent for publication}

Not applicable.

\section{Competing interests}

The authors declare that they have no competing interests.

\section{Author details}

'Division of Genetics and Mutagenesis, National Institute of Health Sciences, 3-25-26 Tono-machi, Kawasaki-ku, Kawasaki, Kanagawa 210-9501, Japan. ${ }^{2}$ Tokyo Laboratory, BoZo Research Center Inc., 1-3-11, Hanegi, Setagaya-ku, Tokyo 156-0042, Japan. ${ }^{3}$ AstraZeneca KK, 3-1 Ofuka-cho, Kita-ku, Osaka 530-0011, Japan. ${ }^{4}$ Ina Research Inc., 2148-188 Nishiminowa, Ina-shi, Nagano 399-4501, Japan. ${ }^{5}$ Scientific Product Assessment Center, R\&D Group, Japan Tobacco Inc., 6-2, Umegaoka, Aoba-ku, Yokohama, Kanagawa 227-8512, Japan. ${ }^{6}$ Yakult Central Institute, 5-11 Izumi, Kunitachi-shi, Tokyo 186-8650, Japan. ${ }^{7}$ Chemicals Evaluation and Research Institute, Japan, 3-822, Ishii-machi, Hita-shi, Oita 877-0061, Japan. ${ }^{8}$ Astellas Pharma Inc., 21, Miyukigaoka, Tsukuba-shi, Ibaraki 305-8585, Japan. ${ }^{9}$ Genotoxicology Laboratory, BioSafety Research Center Inc., 582-2 Shioshinden, Iwata-shi, Shizuoka 437-1213, Japan. ${ }^{10}$ Chugai Pharmaceutical Co., Ltd, 1-135, Komakado, Gotemba, Shizuoka 412-8513, Japan. ${ }^{11}$ Toxicology Research Department, Teijin Institute for Bio-medical Research, Teijin Pharma Limited, 4-3-2, Asahigaoka, Hino, Tokyo 191-8512, Japan. ${ }^{12}$ Nonclinical Research Center, LSI Medience Corporation, 14-1, Sunayama, Kamisu-shi, Ibaraki 314-0255, Japan. ${ }^{13}$ R\&D Safety Science Research, Kao Corporation, Haga-Gun, Tochigi, Japan. ${ }^{14}$ Laboratory of Proteomics for Drug Discovery, Center for Drug Design Research, National Institutes of Biomedical Innovation, Health and Nutrition, 7-6-8 Saito-Asagi, Ibarak, Osaka 567-0085, Japan. ${ }^{15}$ School of Nursing, University of Shizuoka, 52-1 Yada, Suruga-ku, Shizuoka 422-8526, Japan. ${ }^{16}$ Division of Pathology, National Institute of Health Sciences, 3-25-26 Tono-machi, Kawasaki-ku, Kawasaki, Kanagawa 210-9501, Japan.

\section{Received: 7 October 2020 Accepted: 16 February 2021} Published online: 06 March 2021

\section{References}

1. $\quad \mathrm{ICH}$. ICH guideline M7 - genotoxic impurities - assessment and control of DNA reactive (mutagenic) impurities to limit potential carcinogenic risk. Guideline. 2014;44:30 Available from: http://www.ich.org/products/ guidelines/multidisciplinary/article/multidisciplinary-guidelines.html.

2. Hardy A, Benford D, Halldorsson T, Jeger M, Knutsen HK, More S, et al. Clarification of some aspects related to genotoxicity assessment. EFSA J. 2017;15(12):e05113.

3. ECHA. Chapter R.7a: endpoint specific guidance. In: Guid. Inf. Requir. Chem. Saf. Assessment. Version 6.0; 2017

4. Kirkland D, Aardema M, Henderson L, Müller L. Evaluation of the ability of a battery of three in vitro genotoxicity tests to discriminate rodent carcinogens and non-carcinogens: I. sensitivity, specificity and relative predictivity. Mutat Res Genet Toxicol Environ Mutagen. 2005;584:1-256.

5. Matthews EJ, Kruhlak NL, Cimino MC, Benz RD, Contrera JF. An analysis of genetic toxicity, reproductive and developmental toxicity, and carcinogenicity data: I. identification of carcinogens using surrogate endpoints. Regul Toxicol Pharmacol. 2006;44:83-96.

6. Tweats D, Bourdin Trunz B, Torreele E. Genotoxicity profile of fexinidazole--a drug candidate in clinical development for human African trypanomiasis (sleeping sickness). Mutagenesis. 2012;27(5):523-32. https://doi.org/10.1093/ mutage/ges015 Epub 2012 Apr 26. PMID: 22539226.

7. OECD. Guidance document for the use of adverse outcome pathways in developing Integrated Approaches to Testing and Assessment (IATA). OECD Guidel Test Chem. 2016

8. Fujita $Y$, Honda H, Yamane M, Morita T, Matsuda T, Morita O. A decision tree-based integrated testing strategy for tailor-made carcinogenicity evaluation of test substances using genotoxicity test results and chemical spaces. Mutagenesis. 2019;34(1):101-9.

9. European Commission. SCCS (Scientific Committee on Consumer Safety), SCCS notes of guidance for the testing of cosmetic ingredients and their safety evaluation 10th revision: SCCS; 2018. Available from: http://ec.europa. eu/health//sites/health/files/scientific_committees/consumer_safety/docs/ sccs_O_190.pdf

10. Committee S, Sccs CS. Scientific Committee on Consumer Safety Basic Brown 17 COLIPA $n^{\circ}$ B007. 2014

11. Pfuhler S, Pirow R, Downs TR, Haase A, Hewitt N, Luch A, et al. Validation of the $3 \mathrm{D}$ reconstructed human skin comet assay, an animal-free alternative for following-up positive results from standard in vitro genotoxicity assays. Mutagenesis. 2020;geaa009. https://doi.org/10.1093/mutage/geaa009.

12. SCCP. ADDENDUM to the SCCS's notes of guidance for the testing of cosmetic ingredients and their safety evaluation, 8th revision. The SCCS adopted this Addendum on 9 April 2014 by written procedure, SCCS/1501/ 12 (2014).

13. Ates G, Raitano G, Heymans A, Van Bossuyt M, Vanparys P, Mertens B, et al. In silico tools and transcriptomics analyses in the mutagenicity assessment of cosmetic ingredients: a proof-of-principle on how to add weight to the evidence. Mutagenesis. 2016;31:453-61 Oxford Academic.

14. Kirkland, et al. Can in vitro mammalian cell genotoxicity test results be used to complement positive results in the Ames test and help predict carcinogenic or in vivo genotoxic activity? I. Reports of individual databases presented at an EURL ECVAM Workshop. Mutat Res Genet Toxicol Environ Mutagen. 2014;775-776:55-68.

15. Kirkland, et al. Can in vitro mammalian cell genotoxicity test results be used to complement positive results in the Ames test and help predict carcinogenic or in vivo genotoxic activity? II. Construction and analysis of a consolidated database. Mutat Res Genet Toxicol Environ Mutagen. 2014; 775-776:69-80.

16. Negrini S, Gorgoulis VG, Halazonetis TD. Genomic instability an evolving hallmark of cancer. Nat Rev Mol Cell Biol. 2010;11:220-8.

17. OECD. Test No. 490: In vitro mammalian cell gene mutation tests using the thymidine kinase gene: OECD Guidelines for the Testing of Chemicals, OECD, Paris (2016). https://doi.org/10.1787/9789264264908-en.

18. Zeiger E, Anderson B, Haworth S, Lawlor T, Mortelmans K. Salmonella mutagenicity tests: $V$. Results from the testing of 311 chemicals. Environ Mol Mutagen. 1992;19:2-141 John Wiley \& Sons, Ltd.

19. Dunkel VC, Zeiger E, Brusick D, McCoy E, McGregor D, Mortelmans K, et al Reproducibility of microbial mutagenicity assays: II. Testing of carcinogens and noncarcinogens in Salmonella typhimurium and Escherichia coli. Environ Mutagen. 1985;7:1-19.

20. National Cancer Institute CARCINOGENESIS Technical Report Series 33 No. 177. 1979. Available from: https://ntp.niehs.nih.gov/ntp/htdocs/lt_rpts/tr177.pdf. Accessed 16 Sept 2020.

21. Claxton LD, Dearfield KL, Spanggord RJ, Riccio ES, Mortelmans K. Comparative mutagenicity of halogenated pyridines in the Salmonella typhimurium/mammalian microsome test. Mutat Res. 1987;176:185-98.

22. National Cancer Institute CARCINOGENESIS Technical Report Series No. 178. 1979. Available from: https://ntp.niehs.nih.gov/ntp/htdocs/tt_rpts/tr178.pdf. Accessed 16 Sept 2020.

23. Toyoda-Hokaiwado N, Inoue T, Masumura K, Hayashi H, Kawamura Y, Kurata $Y$, et al. Integration of in vivo genotoxicity and short-term carcinogenicity assays using F344 gpt delta transgenic rats: In vivo mutagenicity of 2,4diaminotoluene and 2,6-diaminotoluene structural isomers. Toxicol Sci. 2010;114:71-8.

24. National Cancer Institute CARCINOGENESIS Technical Report Series No. 200 NTP No. 80-20. 1980. Available from: https://ntp.niehs.nih.gov/ntp/htdocs/ It_rpts/tr200.pdf. Accessed 16 Sept 2020. 
25. Chung KT, Murdock CA, Stevens SE, Li YS, Wei Cl, Huang TS, et al. Mutagenicity and toxicity studies of p-phenylenediamine and its derivatives. Toxicol Lett. 1995;81:23-32.

26. National Cancer Institute CARCINOGENESIS Technical Report Series No. 126. 1978. Available from: https://ntp.niehs.nih.gov/ntp/htdocs/lt_rpts/tr126.pdf. Accessed 16 Sept 2020.

27. Oberly TJ, Kokkino AJ, Bewsey BJ, Richardson KK. Mutagenicity evaluation of HC Blue No. 1 and HC Blue No. 2. III. Effects in the Salmonella typhimurium/ Escherichia coli reversion assay and the mouse lymphoma L5178Y TK+/forward mutation assay. Mutat Res. 1990;241:151-9.

28. Zeiger E, Anderson B, Haworth S, Lawlor T, Mortelmans K. Salmonella mutagenicity tests: IV. Results from the testing of 300 chemicals. Environ Mol Mutagen. 1988;11:1-157.

29. National Toxicology Program Technical Report Series No. 293. 1985. Available from: https://ntp.niehs.nih.gov/ntp/htdocs/lt_rpts/tr293.pdf. Accessed 16 Sept 2020.

30. National Toxicology Program Technical Report Series No. 276. 1985. Available from: https://ntp.niehs.nih.gov/ntp/htdocs/lt_rpts/tr276.pdf. Accessed 16 Sept 2020.

31. Rumsby $P$, Lawton $L$, Ewence $A$, Rockett $L$, Hall $T$, James $H$, Jackson $P$. Review of the current toxicological and occurrence information available on iodinated disinfection by-products. DEFRA 7883.03 (DWI 70/2/233). Swindon; 2009. www.wrcplc.co.uk.

32. National Cancer Institute CARCINOGENESIS Technical Report Series No. 110. 1978. Available from: https://ntp.niehs.nih.gov/ntp/htdocs/lt_rpts/tr110.pdf. Accessed 16 Sept 2020.

33. National Toxicology Program. 4-Nitroanthranilic acid (619-17-0) | Chemical Effects in Biological Systems. Available from: https://manticore.niehs.nih.gov/ cebssearch/test_article/619-17-0. Cited 2020 Sep 14.

34. National Cancer Institute CARCINOGENESIS Technical Report Series No. 109. 1978. Available from: https://ntp.niehs.nih.gov/ntp/htdocs/lt_rpts/tr109.pdf. Accessed 16 Sept 2020.

35. Mortelmans K, Haworth S, Lawlor T, Speck W, Tainer B, Zeiger E. Salmonella mutagenicity tests: II. Results from the testing of 270 chemicals. Environ Mutagen. 1986:8:1-119.

36. National Cancer Institute CARCINOGENESIS Technical Report Series No. 64 1978. Available from: https://ntp.niehs.nih.gov/ntp/htdocs/lt_rpts/tr064.pdf. Accessed 16 Sept 2020.

37. Shahin MM, Von Borstel RC. Comparisons of mutation induction in reversion systems of Saccharomyces cerevisiae and Salmonella typhimurium. Mutat Res. 1978;53:1-10.

38. IARC Monographs on the evaluation of the carcinogenic risk of chemicals to man; Some aromatic amines and related nitro compounds -hair dyes, colouring agents and miscellaneous industrial chemicals. Lyon; 1978;16. ISBN; 9283212169

39. Searle CE, Harnden DG, Venitt S, Gyde OHB. Carcinogenicity and mutagenicity tests of some hair colourants and constituents. Nature. 1975; 255:506-7.

40. U.S. Department of HealthEducation, and Welfare, National Toxicology Program. Bioassay of 4-Nitro-o-phenylenediamine for possible carcinogenicity. National Cancer Institute Carcinogenesis technical report series no. 180. 1979.

41. National Cancer Institute CARCINOGENESIS Technical Report Series No. 180. 1979. Available from: https://ntp.niehs.nih.gov/ntp/htdocs/lt_rpts/tr180.pdf. Accessed 16 Sept 2020.

42. Omori T, Honma M, Hayashi M, Honda Y, Yoshimura I. A new statistical method for evaluation of L5178Ytk+/- mammalian cell mutation data using microwell method. Mutat Res Genet Toxicol Environ Mutagen. 2002;517: 199-208.

43. Simpson DG, Margolin BH. Recursive nonparametric testing for doseresponse relationship subject to downturns at high dose. Biometrika. 1986; 73:589-96.

44. Masuda T, Tomita M, Ishihama Y. Phase transfer surfactant-aided trypsin digestion for membrane proteome analysis. J Proteome Res. 2008:7:731-40 American Chemical Society.

45. Adachi J, Hashiguchi K, Nagano M, Sato M, Sato A, Fukamizu K, et al. Improved proteome and phosphoproteome analysis on a cation exchanger by a combined acid and salt gradient. Anal Chem. 2016;88:7899-903.

46. Scientific Committee on Consumer Safety, Opinion on toluene-2,5-diamine and its sulfate. Colipa n A5. Brussels: European Commission; 2012
47. Mitchell AD, Auletta AE, Clive D, Kirby PE, Moore MM, Myhr BC. The L5178Y/ tk(+/-) mouse lymphoma specific gene and chromosomal mutations assay: a phase III report of the U.S. environmental protection agency Gene-Tox program. Mutat Res. 1997:394:177-303.

48. Environemental Protection Agency. Provisional peer reviewed toxicity values for 2,6-Toluenediamine. 2005; Available from: https://cfpub.epa.gov/ncea/ pprtv/documents/Toluenediamine26.pdf.

49. EURL ECVAM genotoxicity and carcinogenicity consolidated database. Available from: https://ec.europa.eu/jrc/en/scientific-tools/Ames. Accessed 22 Dec 2020.

50. McGregor DB, Brown A, Cattanach P, Edwards I, McBride D, Caspary WJ. Responses of the L5178Y tk+/tk- mouse lymphoma cell forward mutation assay ii: 18 coded chemicals. Environ Mol Mutagen. 1988;11:91-118.

51. National Toxicology Program. Mouse lymphoma assay; Aliquot No. 721150. Available from: https://manticore.niehs.nih.gov/cebssearch/test_article/619-17-0. Accessed 22 Dec 2020.

52. Mitchell AD, Rudd CJ, Caspary WJ. Evaluation of the L5178Y mouse lymphoma cell mutagenesis assay: Intralaboratory results for sixty-three coded chemicals tested at sri international. Environ Mutagen Environ Mol Mutagen. 1988;12:37-101.

53. Myhr BC, Caspary WJ. Evaluation of the L5178Y mouse lymphoma cell mutagenesis assay: Intralaboratory results for sixty-three coded chemicals tested at litton bionetics, inc. Environ Mol Mutagen. 1988;12:103-94.

54. NTP database; 2,5-Toluenediamine sulfate 10736-T. Available from: https:// ntp.niehs.nih.gov/whatwestudy/testpgm/status/ts-10736-t.html?utm_ source=direct\&utm_medium=prod\&utm_campaign=ntpgolinks\&utm_term= ts-10736-t. Cited 2020 Aug 14.

55. Honma M, Hayashi M. Comparison of in vitro micronucleus and gene mutation assay results for p53-competent versus p53-deficient human lymphoblastoid cells. Environ Mol Mutagen. 2011;52(5):373-84. https://doi. org/10.1002/em.20634 Epub 2010 Oct 20. PMID: 20963812.

56. Whitwell J, Smith R, Jenner K, Lyon H, Wood D, Clements J, Aschcroft-Hawley K, Gollapudi B, Kirkland D, Lorge E, Pfuhler S, Tanir JY, Thybaud V. Relationships between p53 status, apoptosis and induction of micronuclei in different human and mouse cell lines in vitro: Implications for improving existing assays. Mutat Res Genet Toxicol Environ Mutagen. 2015:789-790:7-27. https:/doi. org/10.1016/j.mrgentox.2015.05.011 Epub 2015 May 30. PMID: 26232254.

57. Zeiger E. Identification of rodent carcinogens and noncarcinogens using genetic toxicity tests: premises, promises, and performance. Regul Toxicol Pharmacol. 1998;28(2):85-95. https://doi.org/10.1006/rtph.1998.1234 PMID: 9927558.

58. Morita T, Hamada S, Masumura K, Wakata A, Maniwa J, Takasawa H, Yasunaga K, Hashizume T, Honma M. Evaluation of the sensitivity and specificity of in vivo erythrocyte micronucleus and transgenic rodent gene mutation tests to detect rodent carcinogens. Mutat Res Genet Toxicol Environ Mutagen. 2016;802:1-29. https://doi.org/10.1016/j.mrgentox.2016.03. 008 Epub 2016 Mar 21. PMID: 27169373.

59. National Toxicology Program. Testing Status of 4-(Chloroacetyl) acetanilide 10592-P, No.223043. Available from: https:/ntp.niehs.nih.gov/whatwestudy/ testpgm/status/ts-10592-p.html?utm_source=direct\&utm_medium=prod\&utm_ campaign=ntpgolinks\&utm term=ts-10592-p. Accessed 22 Dec 2020.

60. National Toxicology Program. Testing status of 2-Chloromethylpyridine hydrochloride 10738-C, No.145263, 448657, A65556, 861777, and 145263, NTP. Available from: https://ntp.niehs.nih.gov/whatwestudy/testpgm/status/ ts-10738-c.html?utm_source=direct\&utm_medium=prod\&utm_campaign= ntpgolinks\&utm_term=ts-10738-c. Accessed 22 Dec 2020.

61. National Toxicology Program. Testing status of 8-Hydroxyquinoline 10598-N, No. 470651, 592699, 616445, 375977, 980523, and 470651. Available from: https://ntp.niehs.nih.gov/whatwestudy/testpgm/status/ts-10598-n. html?utm source $=$ direct\&utm medium $=$ prod\&utm campaign $=$ ntpgolinks\&utm_term=ts-10598-n. Accessed 22 Dec 2020.

62. National Toxicology Program. Testing status of 1-Nitronaphthalene 10425-R No. 153730. Available from: https://ntp.niehs.nih.gov/whatwestudy/testpgm/ status/ts-10425-r.html?utm_source=direct\&utm_medium=prod\&utm_campa ign=ntpgolinks\&utm_term=ts-10425-r. Accessed 22 Dec 2020.

63. National Toxicology Program. Testing status of 4-Nitro-o-phenylenediamine 10476-J, No. 704945, 549927, A82327, and 704945, NTP. Available from: https://ntp.niehs.nih.gov/whatwestudy/testpgm/status/ts-10476-j.html?utm_ source=direct\&utm_medium=prod\&utm_campaign=ntpgolinks\&utm_term= ts-10476-j. Accessed 22 Dec 2020 
64. Martin CN, Beland FA, Roth RW, Kadlubar FF. Covalent binding of benzidine and $n$-acetylbenzidine to dna at the c-8 atom of deoxyguanosine in vivo and in vitro. Cancer Res. 1982;42:2678-86.

65. Murata M, Kawanishi S. Mechanisms of oxidative DNA damage induced by carcinogenic arylamines. Front Biosci. 2011;16:1132-43.

66. Ziegler DM, Ansher SS, Nagata T, Kadlubar FF, Jakoby WB. N-methylation: potential mechanism for metabolic activation of carcinogenic primary arylamines. Proc Natl Acad Sci U S A. 1988;85:2514-7.

67. O'Brien KAF, Gatehouse DG, Tiley M. Induction of mutations in TK6 human lymphoblastoid cells by ethyl methanesulphonate, benzo[ a ]pyrene and benzidine. Mutagenesis. 1990;5:55-60 Oxford Academic.

68. Myhr BC, Caspary WJ, Holden HE. Chemical mutagenesis at the thymidine kinase locus in L5178Y mouse lymphoma cells: results for 31 coded compounds in the national toxicology program. Environ Mol Mutagen. 1991;18:51-83

69. McGregor DB, Edwards I, Roland Wolf C, Forrester LM, Caspary WJ. Endogenous xenobiotic enzyme levels in mammalian cells. Mutat Res. 1991; 261:29-39.

70. Zanoni TB, Hudari F, Munnia A, Peluso M, Godschalk RW, Zanoni MVB, et al. The oxidation of p-phenylenediamine, an ingredient used for permanent hair dyeing purposes, leads to the formation of hydroxyl radicals: oxidative stress and DNA damage in human immortalized keratinocytes. Toxicol Lett. 2015;239: 194-204. https://doi.org/10.1016/j.toxlet.2015.09.026 Elsevier Ireland Ltd.

71. Chao MW, Kim MY, Ye W, Ge J, Trudel L, Belanger CL, et al. Genotoxicity of 2,6- and 3,5-dimethylaniline in cultured mammalian cells: the role of reactive oxygen species. Toxicol Sci. 2012;130:48-59.

72. Chao MW, Erkekoglu P, Tseng CY, Ye W, Trudel LJ, Skipper PL, et al. Intracellular generation of ROS by 3,5-dimethylaminophenol: persistence, cellular response, and impact of molecular toxicity. Toxicol Sci. 2014;141:300-13.

73. Gold LS, de Veciana M, Backman GM, Magaw R, Lopipero P, Smith M, et al. Chronological supplement to the carcinogenic potency database: standardized results of animal bioassays published through December 1982 Environ Health Perspect. 1986;67:161-200.

74. Taningher M, Peluso M, Parodi S, Ledda-Columbano GM, Columbano A Genotoxic and non-genotoxi activities of 2,4- and 2,6-diaminotoluene, as evaluated in Fischer-344 rat liver. Toxicology. 1995;99:1-10.

75. Cunningham ML, Foley J, Maronpot RR, Matthews HB. Correlation of hepatocellular proliferation with hepatocarcinogenicity induced by the mutagenic noncarcinogen: carcinogen pair-2,6- and 2,4-diaminotoluene. Toxicol Appl Pharmacol. 1991;107:562-7.

76. George $\mathrm{E}$, Westmoreland $\mathrm{C}$. Evaluation of the in vivo genotoxicity of the structural analogues 2,6-diaminotoluene and 2,4-diaminotoluene using the rat micronucleus test and rat liver UDS assay. Carcinogenesis. 1991;12:2233-7.

77. Cunningham ML, Hayward JJ, Shane BS, Tindall KR. Distinction of mutagenic carcinogens from a mutagenic noncarcinogen in the Big Blue transgenic mouse. Environ Health Perspect. 1996;104(Suppl):683-6.

78. Sui H, Ohta R, Shiragiku T, Akahori A, Suzuki K, Nakajima M, et al. Evaluation of in vivo mutagenicity by 2,4-diaminotoluene and 2,6-diaminotoluene in liver of F344 gpt delta transgenic rat dosed for 28 days: a collaborative study of the gpt delta transgenic rat mutation assay. Genes Environ. 2012;34:25-33.

79. Allavena A, Martelli A, Robbiano L, Brambilla G. Evaluation in a battery of in vivo assays of four in vitro genotoxins proved to be noncarcinogens in rodents. Teratog Carcinog Mutagen. 1992;12:31-41.

80. Sasaki YF, Fujikawa K, Ishida K, Kawamura N, Nishikawa Y, Ohta S, et al. The alkaline single cell gel electrophoresis assay with mouse multiple organs: results with 30 aromatic amines evaluated by the IARC and U.S. NTP. Mutat Res. 1999:440:1-18.

81. Cunningham ML, Burka LT, Matthews HB. Metabolism, disposition, and mutagenicity of 2,6-diaminotoluene, a mutagenic noncarcinogen. Drug Metab Dispos. 1989;17:612-7.

82. Hatch FT, Knize MG, Colvin ME. Extended quantitative structure-activity relationships for 80 aromatic and heterocyclic amines: structural, electronic, and hydropathic factors affecting mutagenic potency. Environ Mol Mutagen. 2001;38:268-91.

83. Revollo J, Petibone DM, McKinzie P, Knox B, Morris SM, Ning B, Dobrovolsky $\mathrm{VN}$. Whole genome and normalized mRNA sequencing reveal genetic status of TK6, WTK1, and NH32 human B-lymphoblastoid cell lines. Mutat Res Genet Toxicol Environ Mutagen. 2016;795:60-9.

84. Prival MJ, Dunkel VC. Reevaluation of the mutagenicity and carcinogenicity of chemicals previously identified as "false positives" in the Salmonella typhimurium mutagenicity assay. Environ Mol Mutagen. 1989;13:1-24.
85. Burnett CM, Corbett JF. Failure of short-term in vitro mutagenicity tests to predict the animal carcinogenicity of hair dyes. Food Chem Toxicol. 1987;25: 703-7.

86. Kirkland DJ, Aardema M, Banduhn N, Carmichael P, Fautz R, Meunier JR, et al. In vitro approaches to develop weight of evidence (WoE) and mode of action (MoA) discussions with positive in vitro genotoxicity results. Mutagenesis. 2007;22:161-75.

\section{Publisher's Note}

Springer Nature remains neutral with regard to jurisdictional claims in published maps and institutional affiliations.
Ready to submit your research? Choose BMC and benefit from:

- fast, convenient online submission

- thorough peer review by experienced researchers in your field

- rapid publication on acceptance

- support for research data, including large and complex data types

- gold Open Access which fosters wider collaboration and increased citations

- maximum visibility for your research: over $100 \mathrm{M}$ website views per year

At $\mathrm{BMC}$, research is always in progress.

Learn more biomedcentral.com/submissions 